\title{
Making Corporate Social Responsibility Pay
}

\author{
Dorothy S. Lund 1
}

\begin{abstract}
With the recognition that adequate externality regulation is unlikely to be forthcoming, legal scholars, politicians, major shareholders, and corporate stakeholders have joined in urging companies to practice corporate citizenship. In this Article, I explain why much of this advocacy is unlikely to alter corporate decisionmaking to the desired extent. In particular, proponents of corporate social responsibility ask fiduciaries to operate against a deeply-ingrained incentive structure that pushes them to maximize shareholder wealth as a first priority.

This Article proposes a way forward that works within the wealth-maximization framework, but could, under certain circumstances, encourage corporations to prioritize stakeholder goals. More specifically, individuals could use "corporate social responsibility bonds," to offset costs associated with prosocial corporate decision-making. The intuition is as follows: if it is welfaremaximizing for individuals to see corporations make public-interested choices, there should be a possible Coasian bargain between those individuals and the corporation. In such situations, an issuer could create bond to finance a predetermined public-interested corporate decision, thereby turning stakeholders into creditors with governance rights. Any individual for whom the choice is welfare-maximizing could participate; their loan would be forgiven if the decision was made, and if it is not, the individuals would get their money back plus interest.

More broadly, the insight that the individuals with the strongest interest in seeing corporations pursue corporate social responsibility goals are not always the shareholders has consequences for corporate law and corporate governance. In particular, it cautions that we should recognize the limits of corporate law and shareholder activism to achieve socially optimal levels of corporate responsibility. The more difficult question is whether and how to reorient our corporate law system away from shareholders and toward other constituencies. As that project forges on, this Article proposes action that could allow corporate outsiders to influence corporate behavior without any delay — one decision at a time.
\end{abstract}

1 Assistant Professor, USC Gould School of Law. Thanks to Scott Altman, Alon Brav, Jesse Fried, Daniel Hemel, Erik Hovenkamp, Cathy Hwang, Dan Klerman, Matt Levine, Saul Levmore, Ed McCaffery, Elizabeth Pollman, Julianna Pillemer, Leo Strine, Jr., Kirby Smith, Michael Simkovic, Mike Vandenbergh, Andrew Verstein, as well as participants in the Columbia Law School Blue Sky Lunch, for helpful comments, and Taylor Apodaca for excellent research assistance. Email: dlund@law.usc.edu. 
I. Introduction...........................................................

II. Why Companies Won't Make Public Interested Decisions ....................... 9

A. Takeover Markets...................................................... 10

B. Shareholder Activism..................................................... 11

C. Executive Compensation................................................... 13

III. Corporate Social Responsibility Bonds ................................... 14

A. The Possibilities........................................................ 17

i. Beneficial Secondary Effects ...................................... 18

ii. Overcoming Coordination Costs......................................... 19

iii. Higher Marginal Returns from Corporate Philanthropy.......................21

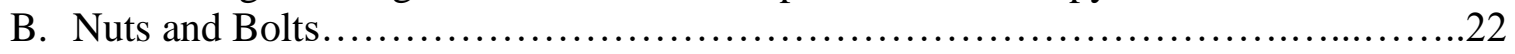

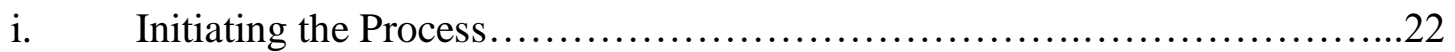

ii. The Offering Document............................................ 24

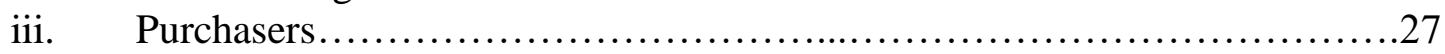

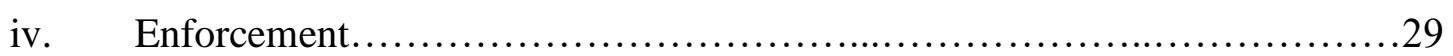

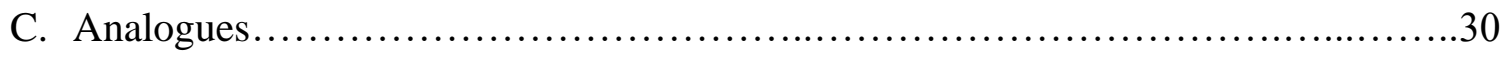



ii. Green Bonds............................................................... 32

iii. Carbon Offsets........................................................ 34

iv. Legal Analogues.................................................... 36



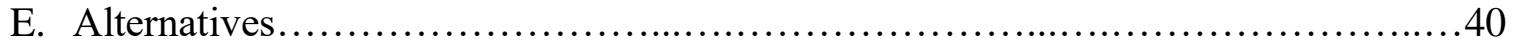

IV. Broader Implications .......................................................41

V. Conclusion............................................................ 45 


\section{Making Corporate Social Responsibility Pay}

\section{Introduction}

The world is clamoring for corporations to serve society. This advocacy is well-directed: some U.S. corporations are as powerful as small countries,2 and constraints on their behavior are eroding. 3 Not only that, the past few decades have shown how the pursuit of profit can harm society: the financial crisis that brought down the global economy; 4 the Deepwater Horizon oil spill that polluted 1,100 miles of shoreline, 5 the social media companies that enabled Russian hackers to meddle in the 2016 presidential election;6 the layoffs, wage cuts, and offshoring that have exacerbated economic inequality, 7 etc.

But herein lies the paradox: Corporations are the source of many problems, but they are also expected to solve them. For example, a popular solution among legal academics is to reconceptualize the purpose of the corporation. These academics contend that it is no longer normatively desirable nor descriptively accurate to say that the law requires corporate fiduciaries to maximize shareholder wealth.8 Instead, corporate law should adopt a "stakeholder model" that allows fiduciaries to consider how the company's activities affect employees, consumers, the environment, and the communities that the company operates in. 9

2 See, e.g., Sarah Anderson \& John Cavanagh, Inst. For Policy Studies, Top 200 (2000); Paragh Khanna top 25 by David Francis, These 25 Companies Are More Powerful Than Many Countries, FP, https://foreignpolicy.com/2016/03/15/these-25-companies-are-more-powerful-than-many-countries-multinationalcorporate-wealth-power/ (last visited Oct. 20, 2019). 3 Samantha Gross, The Danger in Deregulation, BROOKINGS: PLANETPOLICY (Jan. 9, 2018), https://www.brookings.edu/blog/planetpolicy/2018/01/09/the-danger-in-deregulation/; Mark Lebovitch \& Jacob Spaid, Bernstein Litowitz Berger \& Grossman LLP, In Corporations We Trust: Ongoing Deregulation and Government Protections, HARV. L. SCH. F. ON CORP. GOVERNANCE \& FIN. REG. (Feb. 6, 2019), https://corpgov.law.harvard.edu/2019/02/06/in-corporations-we-trust-ongoing-deregulation-and-governmentprotections/.

4 William W. Bratton \& Michael L. Wachter, The Case Against Shareholder Empowerment, 158 U. PA. L. REV. 653 (2010).

5 Cleanup Efforts, ENCYCLOPÆDIA BRITTANICA, https://www.britannica.com/event/Deepwater-Horizon-oilspill/Cleanup-efforts (last visited Oct. 20, 2019).

6 Peter Overby, Facebook Acknowledges Russian Ads in 2016 Election. Will Investigations Follow?, npr: NPRPolitics (Sept. 8, 2017), https:/www.npr.org/2017/09/08/549284183/facebook-acknowledges-russian-ads-in2016-election-will-investigations-follow.

7 Thomas PiketTy, CAPITAL In The TwEnTY-FIRST CENTURY (Arthur Goldhammer trans., President and Fellows of Harvard College 2014) (2013).

8 See, e.g., Colin Mayer, Prosperity (2019); Lynn Stout, The Shareholder Value Myth (2012); Margaret M. Blair \& Lynn A. Stout, A Team Production Theory of Corporate Law, 85 VA. L. REV. 247, 308 (1999); Einer Elhauge, Sacrificing Corporate Profits in the Public Interest, 80 N.Y.U. L. REV. 733, 763-69 (2005) (arguing that corporate managers have the discretion to sacrifice corporate profits in favor of the public interest under Delaware law); Lyman Johnson, Unsettledness in Delaware Corporate Law: Business Judgment Rule, Corporate Purpose, 38 DEL. J. CORP. L. 405, 432 (2013) (arguing that Delaware law is unsettled on the question of whether corporations are required to advance the long-term interests of stockholders); Lynn A. Stout, Why We Should Stop Teaching Dodge v. Ford, 3 VA. L. \& Bus. REV. 163 (2008). This advocacy is not limited to legal academics. See, e.g., Oliver Hart \& Luigi Zingales, Companies Should Maximize Shareholder Welfare Not Market Value, 2 J.L. FIN. \& ACCT. 247 (2017).

9 Id. 
There are signs indicating that this advocacy is beginning to have some traction. For example, in August 2018, Elizabeth Warren introduced the Accountable Capitalism Act, federal legislation that would make clear that corporate fiduciaries have a duty to consider not just shareholder interests, but also the interests of employees, customers, the community, and the environment.10 Around that same time, Larry Fink, the CEO of BlackRock, one of the largest and most influential institutional shareholders in the world, issued the first of three letters urging CEOs to serve society.11 BlackRock, along with peer institutional investors Vanguard and State Street, has since committed to engaging with companies until they articulate a corporate purpose that benefits the public. 12 In addition, in August 2019, the Business Roundtable announced a new statement on the purpose of the corporation that affirmed that companies should be managed for the benefit of all stakeholders - including customers, employees, suppliers, communities and shareholders.13 One hundred and eighty-one CEOs signed the statement.14

But cynical observers will hesitate before congratulating the legal scholars who have pushed companies to articulate a broader corporate objective. Presumably, the reason for their advocacy was not to provide CEOs with an additional marketing tool; it was to change corporate decisionmaking for the better. And there is very little evidence that the latter phenomenon has occurred. As just one example, days after announcing that Amazon CEO Jeff Bezos had signed the Business Roundtable letter, Whole Foods, a subsidiary of Amazon, announced that it would end medical and health benefits for part-time workers.15

10 S. 3348, 115th Congress (2018). The former Chief Justice of the Delaware Supreme Court, Leo Strine, Jr., has proposed to require major companies to "have board-level committees charged with ensuring fair treatment of employees" and also using "European-style works' councils to increase employee voice." See Leo Strine, Jr., Toward Fair and Sustainable Capitalism: A Comprehensive Proposal to Help American Workers, Restore Fair Gainsharing between Employees and Shareholders, and Increase American Competitiveness by Reorienting Our Corporate Governance System Toward Sustainable Long-Term Growth and Encouraging Investments in America's Future, https://papers.ssrn.com/sol3/papers.cfm?abstract_id=3461924.

11 Larry Fink, Larry Fink's Annual Letter to CEOs A Sense of Purpose, BLACKRock [hereinafter Fink, A Sense of Purpose] https://www.blackrock.com/hk/en/insights/larry-fink-ceo-letter (last visited Oct. 20, 2019); Larry Fink, Larry Fink's 2019 Letter to CEOs Purpose \& Profit, BLACKRock [hereinafter Fink, Purpose \& Profit], https://www.blackrock.com/corporate/investor-relations/larry-fink-ceo-letter (last visited Oct. 20, 2019); Larry Fink, A Fundamental Reshaping of Finance, BLACKRoCK, https://www.blackrock.com/corporate/investor-relations/larryfink-ceo-letter.

12 Andrew Edgecliffe-Johnson, Companies under pressure to declare social purpose,' Financial Times (Aug. 22, 2019), https://www.ft.com/content/7ba44ea8-c4f7-11e9-a8e9-296ca66511c9

13 Business Roundtable Redefines the Purpose of a Corporation To Promote "An Economy That Serves All Americans," Business RoundTABLE (Aug. 19, 2019), https://www.businessroundtable.org/business-roundtableredefines-the-purpose-of-a-corporation-to-promote-an-economy-that-serves-all-americans.

14 Id.

15 Bob Bryan, Amazon-Owned Whole Foods' Decision To Drop Health Benefits for Hundreds of Part-Time Workers Reveals How Promises to Workers Like CEO Jeff Bezos' Recent Pledge are Worthless, Business Insider (Sept. 14, 2019, 1:08 AM), https://www.businessinsider.com/whole-foods-healthcare-amazon-ceo-jeff-bezospromises-business-roundtable-2019-9; see also Jesse Fried, Shareholders Always Come First and That's a Good Thing, Financial Times (Oct. 7, 2009),

https://www.ft.com/content/fff170a0-e5e0-11e9-b8e0-026e07cbe5b4 ("In reality, the Business Roundtable is merely paying lip service to broader social concerns. I predict that the pledge will not actually affect how they run their companies.”); Aneesh Raghunandan and Shiva Rajgopal, Is There Real Virtue Behind the Business

Roundtable's Signaling?, Wall St. J. (Dec. 2, 2019) (collecting data showing that the signatories of the Business Roundtable letter were sixteen times more likely to commit at least one federal compliance violation, including labor and environmental violations, in any given year than peer nonsignatory firms and concluding that the goal of the letter was to preempt regulatory criticism). 
Should we be surprised? Of course not: we should not expect corporations to do anything other than maximize profits when corporate law's incentive structure rewards corporate fiduciaries who maximize shareholder wealth.16 More concretely, corporate law provides shareholders and only shareholders with control rights, which means that fiduciaries are vulnerable to pressure from takeover markets and hedge fund activists when they sacrifice profits to benefit the public.17 Moreover, most executives have their pay and reputation tied to the company's stock price, rendering fiduciaries particularly sensitive to shareholder interests. 18

Put somewhat differently, this wave of stakeholder advocacy does little to change the practical operation of corporate decisionmaking. Corporate fiduciaries already have incentives to engage in prosocial activities when they also maximize profit — and a large and growing literature documents the many ways that corporate social responsibility is wealth maximizing. 19 The difficult question, however, is how to encourage corporations to make public interested choices that are bad for business, or at least, not clearly good.

With that in mind, this Article considers how people might encourage public-interested corporate decisions, defined as decisions that shift profits from shareholders to employees, consumers, the environment, or the broader community. In so doing, I focus on actions that corporate stakeholders can take in the absence of regulation. Optimal externality regulation is a first-best solution, but it is unlikely to manifest;20 therefore, I consider actions stakeholders could

16 See D. Gordon Smith, The Shareholder Primacy Norm, 23 J. CORP. L. 277, 277 (1998) (“The structure of corporate law ensures that corporations generally operate in the interests of shareholders. Shareholders exercise control over corporations by electing directors . . . ."); Leo E. Strine, Jr., Corporate Power Is Corporate Purpose II: An Encouragement for Future Consideration from Professors Johnson and Millon, 74 Wash. \& Lee L. Rev. 1 (2017); Leo E. Strine, Jr., The Dangers of Denial: The Need for a Clear-Eyed Understanding of the Power and Accountability Structure Established by the Delaware General Corporation Law, Wake Forest L. Rev. [hereinafter Strine, The Dangers of Denial], https://www.ssrn.com/abstract=2576389 (describing the DGCL's power structure, which provides rights to shareholders and shareholders only); Leo Strine, Jr., Corporate Power is Corporate Purpose I, https://scholarship.law.upenn.edu/cgi/viewcontent.cgi?article=2724\&context=faculty_scholarship

17 Id.; see also infra section XX. 18 See infra section XX.

${ }_{19}$ Corporate social responsibility may reduce a company's cost of capital, see Sudheer Chava, Environmental Externalities and Cost of Capital, 60 MGMT. SCI. 2223 (2014); may have a positive impact on a company's revenue by reducing litigation, sanctions, and boycott risk, and increasing government support ((Thompson and Cowton (2004), Anderson and Sullivan (1993) and Kassinis and Vafeas (2002)); and lower a company's cost of debt (Bauer and Hann (2010)). See also Robert G. Eccles et al., The Impact of Corporate Sustainability on Organizational Processes and Performance, 60 MGMT. SCI. 2835, 2836 (2014) (describing study finding that companies which voluntarily adopted sustainability policies by 1993 outperformed their counterparts over the long term); Michael E. Porter \& Mark R. Kramer, The Competitive Advantage of Corporate Philanthropy, HARV. BuS. REV., Dec. 2002, at 1 (arguing that "social and economic goals are not inherently conflicting but integrally connected"); https://www.institutionalinvestor.com/article/b1hm5ghqtxj9s7/Where-ESG-Fails\#.XajIH2RniVc.twitter.

${ }_{20}$ Optimal externality regulation is unlikely for several reasons. For one, gridlock in Washington continues to slow the passage of new laws, and has even sidelined regulation with strong popular support. See Tim Wu, The Oppression of the Supermajority, N.Y. TIMES: OPINION (Mar. 5 2019),

https://www.nytimes.com/2019/03/05/opinion/oppression-majority.html. And even if Congress did manage to pass externality regulation, it would likely be the product of a compromise and subject to interest group dynamics. See Henry N. Butler \& Jonathan R. Macey, Externalities and the Matching Principle: The Case for Reallocating Environmental Regulatory Authority, 14 YALE L. \& POL'Y REV. 23 (1996). Indeed, corporations are very willing to spend millions of dollars - either on lobbyists, or on direct candidate contributions - to thwart costly legislation. See 
take on their own. In particular, I explore financial instruments that would create incentives for corporations to act in the public interest.21 The past few years have seen ample innovation in this space: investors can now invest in green bonds or impact bonds, for example. However, these instruments simply make money available for profit-maximizing projects that align with investors' prosocial goals; they do not encourage corporations to make profit sacrificing prosocial decisions. 22

But whenever individuals value a particular course of action more than the costs, it is possible for them to bargain and arrive at the efficient outcome.23 In this vein, this paper considers a "corporate social responsibility bond," a tool that does not exist but that has analogues in law and in finance. This instrument would be a hybrid between a bond and charitable donation, and would essentially support a Coasian bargain between companies and the individuals who desire public interested corporate decisions. 24

The concept is as follows: an issuer (likely a non-profit, to increase the likelihood that the investment would be tax deductible25) would create a bond 26 to raise funds that would support a predetermined public interested corporate decision. The nonprofit would then work with the corporation to implement the decision; the accumulated funds would offset the cost of the decision if it is successfully made, allowing the company to internalize the Coasian bargain. Any investor for whom the choice is welfare-maximizing could contribute; their investment-donation would be

Tim Wu, The Goals of the Corporation and the Limits of the Law, COLuM. L. SCH.: CLS BluE SKy BlOG (Sept. 3, 2019), http://clsbluesky.law.columbia.edu/2019/09/03/the-goals-of-the-corporation-and-the-limits-of-the-law/. This is one reason why advocates of corporate social responsibility have been urging a private sector response. See, e.g., Michael P. VANDENBERGH \& JONATHAn M. Gilligan, BEYOND POLITICS (2017). Others are more optimistic about the prospect of beneficial regulation. See, e.g., Leo E. Strine, Jr., Toward Fair and Sustainable Capitalism, supra note XX.

21 Other private ordering solutions are possible and discussed in Section XX infra.

22 For a discussion of these instruments and their limitations, see notes XX and accompanying text.

23 See Ronald Coase, The Problem of Social Cost, 3 Journal of Law and Economics (1960).

24 Id. In Section XX, I explore other options that would encourage public-interested decisionmaking, such as offering funding at a lower interest rate.

25 It is unlikely that a 501(c)(3) could issue the bond and enable the purchaser to claim a charitable contribution if the investor gets the money back. If a person retains a reversionary interest, they cannot claim a charitable contribution deduction. However, the donor might be able to preserve charitable contribution deductibility by having the money roll over to the charity if the bond fails. In the alternative, the investor could claim a capital loss if the company takes the action in question. See, e.g., Stefan Gottschalk \& Sharif Ford, IRS Addresses Timing of a Worthless Stock Deduction, RSM (Dec. 15, 2016), https://rsmus.com/what-we-do/services/tax/federal-tax/corporatetax-services/irs-addresses-timing-of-a-worthless-stock-deduction.html.

26 I use the term "bond" because it has characteristics that resemble traditional bonds, and in particular, green bonds and impact bonds discussed on page XX. In addition, debt instruments provide lenders with governance rights that would be useful in this context. See Douglas Baird \& Robert Rasmussen, Private Debt and the Missing Lever of Corporate Governance, 154 U. Pa. L. Rev. 1209 (2006). The key difference between a traditional bond and the corporate social responsibility bond is that individuals who fund the latter instrument would not expect to be paid back - the expected return is the social benefit. See Bruce Kogut et al., Social Capital Markets, Harvard Business Review (2019) ("You can think of a charitable donation as an investment... The difference is that the return is not financial. The donor does not expect to get its money back; it expects its money to generate a social benefit. It considers the investment a failure only if the social benefit is not created."). Different versions of this bond are possible and explored supra Section XX. 
forgiven if the decision was made, and if the company fails to act, the investor would get their money back plus interest. 27

Consider the following stylized example of how a corporate social responsibility bond could be used, which illustrates some of the benefits (as well as the drawbacks, which will be discussed in a moment). Suppose a coal-fired power company is facing pressure from environmental advocacy groups to install scrubbers that would reduce air pollution, increasing the life expectancy of employees, as well as people who live near the company's factories.28 But installing scrubbers would cause the company to incur $\$ 150$ million in costs.29 As a result, the company is unlikely to install the scrubbers without regulation, which, as a result of industry lobbying, is not expected to arise. Of course, pressure from environmental advocates, consumers, employees or even shareholders might lead to negative repercussions for the company that fails to install scrubbers, but unless those harms exceed the costs from implementation, the choice will not be made. And this reality holds regardless of the company's legal objective, and regardless of the extent of fiduciary discretion: even if management is permitted to consider the environment or other groups, that leeway will not result in a voluntary decision to sacrifice $\$ 150$ million, which will subject them to negative reputational and financial repercussions, as well as a threat of ouster.

The calculus for the company changes, however, if it has the opportunity to work with a nonprofit issuer and receive funds to offset the costs from implementation. Potential donors include individuals for which the choice would be welfare-maximizing; the most likely source of assets, however, would be a foundation, family office, or endowment seeking an opportunity to make a tangible and measurable impact on social welfare. To provide a sense of this pool of funds, consider that U.S. donors give away an amount roughly equivalent to $2 \%$ of GDP-or approximately $\$ 300$ billion-each year.30 Socially responsible mutual funds might also contribute - indeed, an SRI index fund might promise that, instead of buying and selling shares of companies based on investor ideology (which is unlikely to change corporate behavior and possibly sacrifices investor returns),31 the fund's fees would support worthy corporate social responsibility bonds. 32

27 This penalty for noncompliance serves as a commitment mechanism for the issuer. See Ian Ayres and Michael Abramowicz, Commitment Bonds, https://digitalcommons.law.yale.edu/fss_papers/3702/.

${ }_{28}$ For a description of the costs and benefits of coal plant scrubbers, see Maureen L. Cropper et al., Costs and Benefits of Installing Flue-Gas Desulfurization Units at Coal-Fired Power Plants in India, in 7 INJURY PREVENTION AND ENVIRONMENTAL HeAlth 239 (Charles N. Mock et al. eds., 3rd ed. 2017). Although the Clean Air Act of 1977 essentially mandated that new coal-fired power plants install scrubbers, old companies were grandfathered in. http://www.edf.org/documents/2695_cleanairact.htm. As a result, about 30\% of U.S. power plants lack scrubbers. https://www.nytimes.com/2018/08/24/climate/epa-coal-power-scrubbers.html.

29 See George W. Sharp, EUCG Inc., What's the Scrubber Going To Cost?, POWER (July 15, 2007), https://www.powermag.com/whats-that-scrubber-going-to-cost/?pagenum=4.

30 James Andreoni \& A. Abigail Payne, Charitable Giving, in 5 HANDBOOK OF PubliC Economics 1 (Alan J. Auerbach et al. eds., 2019). This figure excludes the $\$ 50$ billion donated by U.S. charitable organizations each year. See Kogut et al., infra note XX.

31 Paul Brest et al., How Investors Can (and Can't) Create Social Value, 44 J. Corp. L. 205 (2018).

32 As of the beginning of 2018, \$11.6 trillion of all professionally managed assets in the U.S. were in ESG investment strategies. Adam Connaker \& Saadia Madsbjerg, The State of Socially Responsible Investing, HARV. BuS. REV. (Jan. 17, 2019), https://hbr.org/2019/01/the-state-of-socially-responsible-investing.

Assuming investors were willing to pay an additional fee of 10 basis points each year, that would amount to over a billion dollars available to incentivize good corporate behavior. 
Let's assume that the total cost to the company of installing scrubbers is estimated to be $\$ 80$ million, as the coal company would expect a positive reputational boost and heightened employee productivity worth approximately $\$ 70$ million.33 If a bond was issued and funded in that amount, the company would have a difficult time resisting. And if the company installed the scrubbers, the loan would be forgiven; if not, investors would get their money back plus interest.

In this example, the use of the bond would likely be the only way to encourage the corporation to install the scrubbers. As discussed, externality regulation that would push the company to implement scrubbers or otherwise reduce emissions is unlikely; even if regulation did arise, it would likely be the product of compromise, or distorted by interest group dynamics.34 Moreover, most consumers, many of whom live far away from the factories, might not mind that the coal plant is polluting if it leads to cheaper energy prices. Even socially motivated consumers might not feel compelled to boycott the company if most competing coal companies have not installed scrubbers.35 What about shareholders? Although some prosocial shareholders may be willing to bear a hit to the stock price in service of the public good, it is unlikely that the majority will encourage profit sacrificing decisions even when the welfare benefits are very great. 36

Therefore, the bond might be the only way for stakeholders to bring about the desired change. Not only that, by converting outsiders into creditors, the bond could alter other facets of corporate decisionmaking. Perhaps, for example, the bondholders would secure information rights or the right to monitor operations until the decision is made.37 By giving the nonprofit a voice in the room, the bond could ensure that the nonprofits' views are taken into consideration for many months or years, even when the company is doing poorly.

The bond could also have beneficial secondary effects on the market. Indeed, by advertising that it has installed scrubbers, the company's choice could cause consumers to focus on rival companies that have not followed suit, increasing the costs of non-compliance with the developing norm. The social responsibility bond could also alter industry-wide standards in another way: by forcing a company to reduce pollution, the bond removes an incentive for the company to lobby

33 The company would likely have to pay tax on the money that it gets, however, it might be possible to structure the transaction to reduce the tax burden (such as by claiming depreciation for fixed assets).

34 See note XX supra.

35 To Boycott or Not To Boycott: The Consequences of a Protest, WHARTON U. PA.: KNOWLEDGE @ WHARTON (June 9, 2010), https://knowledge.wharton.upenn.edu/article/to-boycott-or-not-the-consequences-of-a-protest/. 36 Madison Condon posits that diversified investors have an incentive to push for action that will sacrifice profits at a single firm if doing so will maximize the value of the entire portfolio. She contends that this explains environmental initiatives undertaken by institutional investors. Externalities and the Common Owner, WASH. L. REV. (forthcoming 2020), https://papers.ssrn.com/sol3/papers.cfm?abstract_id=3378783. But the paradigmatic universal owner is the index fund, which for reasons I explain in Section XX, lacks a financial incentive to invest in the kind of research and engagement necessary to effectively implement a strategy of this kind. Not only that, these institutional investors are operated by managers who are unlikely to sacrifice profits to safeguard the portfolio several decades into the future - even if this is the correct long-term strategy, the fund will suffer from poor performance for the manager's tenure, affecting the amount of fees the manager earns. See Rock and Kahan, supra note XX. In fact, as Condon concedes, these diversified investors maintain that their actions are in fact profit maximizing for the underlying firm. Therefore, it is unlikely that shareholder pushing will lead to routine profit sacrificing in the public interest.

37 See Baird \& Rasmussen, Debt Governance. 
against regulation that would impose the same requirement on rivals. Indeed, the power company might now lobby in favor of regulation. 38

As this example reveals, the social responsibility bond resembles a private Pigouvian subsidy 39 that could be used to alter corporate decisionmaking by changing the set of decisions that are wealth-maximizing. At its best use, a bond could transform industries, ease the prospect of regulation, help prosocial individuals overcome coordination costs, and reverse harmful corporate activities. It does this without requiring any change in the law or corporate governance. Indeed, one of the advantages of the bond is that it works within the wealth-maximization framework, and therefore, does not run a risk of eroding managerial accountability and other inefficiencies associated with a stakeholder model.40 In addition, the use of social responsibility bonds avoids the collateral consequences that flow from consumer boycotts and employee strikes - by targeting individual decisions and offering incentives for corporations to make them, the bond rewards good behavior, rather than punishing corporate actors and the guiltless employees that populate them.

But the devil is in the details. Indeed, corporate social responsibility bonds are fraught with complications that could render them not useful or even harmful under certain circumstances. For example, the bonds could be impossible to price because of information asymmetries, lead to moral hazard for companies, and could result in harmful distributive consequences. In addition, companies might not be receptive to accepting funds when doing so will focus attention on their harmful practices. (I discuss these and other possible pitfalls in Section XX). Therefore, corporate social responsibility bonds should not be seen as a cure for every instance of corporate irresponsibility, but a complement to action taken on other grounds: from shareholders, consumers, employees, and regulators.

More broadly, the insight at the core of this Article - that the individuals with the strongest interest in seeing corporations pursue corporate social responsibility goals are not necessarily the shareholders-has consequences for corporate law and corporate governance. In particular, we

${ }_{38}$ Consider Amazon's changed lobbying position on laws requiring online retailers to pay sales tax. Amazon initially opposed such laws, but once the Supreme Court ruled that state and local governments could require online merchants to levy sales tax, even when that retailer had no physical presence in the state, Amazon began lobbying in favor of laws that would require sales taxes on all internet purchases. Kyung M. Song, Amazon Lobbies Heavily for Internet Sales Tax, SEATTLE TIMES (Sept. 7, 2013, 7:45 PM), https://www.seattletimes.com/seattle-news/amazonlobbies-heavily-for-internet-sales-tax/.

39 Pigouvian subsidies are direct payments from the government to firms to encourage beneficial activities so that corporate decisions coincide with socially optimal allocations. See Garth Heutel, Subsidies, Economics Faculty Publications Paper 20 (2014). But the corporate social responsibility bond is not calibrated to maximize public welfare, but rather private welfare. And because individuals might also fail to internalize all of the costs of corporate harm, it is likely that relying on bonds alone will not result in an optimal level of corporate social responsibility from a public welfare perspective. This is why this instrument is intended to be a complement to regulation, rather than a substitute.

40 See Mark J. Roe, The Shareholder Wealth Maximization Norm and Industrial Organization, 149 U. PA. L. REV. 2063, 2065 (2001) (“'A] stakeholder measure of managerial accountability could leave managers so much discretion that managers could easily pursue their own agenda, one that might maximize neither shareholder, employee, consumer, nor national wealth, but only their own."); Strine, The Dangers of Denial, supra note 16, at (describing how constituency statutes "largely shift[] power to the directors to couch their own actions in whatever guise they find convenient, without making them more accountable to any interest"); Jean Tirole, Corporate Governance, 69 Econometrica 1 ("the implementation of the stakeholder society strikes three rocks: dearth of pledgeable income, deadlocks in decision-making, and lack of clear mission for management"). 
should recognize the limits of corporate law and shareholder activism to achieve socially optimal levels of corporate responsibility. We should also be skeptical about the growing enthusiasm about shareholders, and specifically, the long-term "universal owners," as the solution to wide-ranging problems, like climate change and systemic risk.41 The paradigmatic universal owner is the index fund, which offers investors market returns for a low cost.42 To keep costs low, index funds minimize overall expenditures, including market research. 43 For this reason, index funds focus on governance reforms that can be implemented at scale.44 They are not well positioned to identify and solve problems that have generated substantial debate among informed researchers, such as how companies can minimize risks from climate change.

From the observation that shareholder control is unlikely to lead to an optimal level of corporate social responsibility emerges the difficult question: whether and how to reorient corporate law away from shareholders and toward a broader set of constituents. Even though shareholder primacy offers many efficiencies, the costs of prioritizing one group at the expense of others may ultimately outweigh the benefits. But a move to a new paradigm is fraught with complications, which may explain the lasting power of the shareholder primacy norm. As that discussion forges on, the bond mechanism would allow corporate outsiders to influence corporate behavior right away.

There is at this moment a massive appetite for corporate social responsibility.45 Impact investing opportunities are everywhere - and most of these are less influential than they first appear.46 This Article explores a possibility that would allow stakeholders to make a concrete and tangible impact on corporate behavior-one decision at a time.

This article proceeds as follows: Part II explains why corporations are unlikely to make public interested decisions, even if they have the legal discretion to do so (as many contend they do). Part III discusses more promising avenues for proponents of corporate social responsibility. It introduces the concept of corporate social responsibility bonds and describes several examples of where they could be used to alter corporate decisionmaking for the better. It also considers analogous concepts in law and finance, including green bonds, carbon offsets, impact bonds, and tax breaks for companies that act in the public interest. And it describes limitations and complications. Part IV discusses broader implications for corporate law and corporate governance. Part V concludes.

II. Why Companies Won’t Make Public Interested Decisions

41 See note 38, supra; see also Yesha Yadav, Too-Big-To-Fail Shareholders, 103 Minn. L. Rev. 587 (2018); Gordon, supra note 65; Strine, Toward Fair and Sustainable Capitalism, supra note XX.

42 Dorothy Lund, The Case Against Passive Shareholder Voting, 43 J. Corp. Law (2017).

43 Id.; Lucian Bebchuk and Scott Hirst, Index Funds and the Future of Corporate Governance: Theory, Evidence, and Policy, 119 Columbia L. Rev. (2019).

44 Id.; Ed Rock and Marcel Kahan, Index Funds and Corporate Governance, Let Shareholders Be Shareholders, Working Paper.

45 Jon Hale, Bucking the Trends, Flows into ESG Funds Set Another Record in 2018, MORNINGSTAR:

SUSTAINABILITY MATTERS (Jan. 24, 2019), https://www.morningstar.com/articles/908665/bucking-the-trend-flowsinto-esg-funds-set-another-record-in-2018.

46 Brest et al, supra note 31. 
The world is ready for corporations to serve society: Legal scholars defend a view of fiduciary obligation that would allow directors and officers to make public interested choices, even those that sacrifice corporate profits. 47 Nearly every state has adopted constituency statutes that allow management teams to consider stakeholder interests, as well as their shareholders.48 Prominent shareholders have made public statements urging CEOs to serve the public interest;49 prominent CEOs have voiced an increased commitment to doing so.50 Likewise, researchers in economics and finance continue to advance a view that profit-maximizing and corporate social responsibility are linked.51

This section shows why much of this advocacy is unlikely to have a dramatic effect on corporate decision-making. 52 The reason is that these advocates of corporate social responsibility either ask corporate fiduciaries to do something they already have incentives to do, or they operate against a deeply-ingrained incentive structure that pushes corporate fiduciaries to maximize shareholder wealth as a first priority. And without an attempt to change that incentive structure, the effect of this pushing will be little more than symbolic. In other words, the problem with much of this advocacy is that it neither requires nor encourages corporations to make different choices than they would otherwise make.

To make this more concrete, assume that the world of corporate decisionmaking can be divided into two categories: those decisions that maximize shareholder wealth, and those that do not. Quite obviously, corporations already have incentives to make choices that maximize shareholder wealth. Of course, this easy answer elides many difficulties: for example, some long-term wealthmaximizing choices may be wealth-sacrificing over a shorter time horizon, or some prosocial projects may be NPV uncertain.53 If there is a risk that an investment in corporate social responsibility will not pay off at all, or that it will pay off years after the management team has departed, management may not make the choice voluntarily. However, equity holders have tools available to push management to consider a longer time horizon if that is the problem. In addition, diversified shareholders may be willing to use these tools to push companies to take risks on NPV uncertain decisions - so long as more than $50 \%$ pay off, they will be better off.

We can see this happening already. In particular, long-term shareholders claim that they use voting and engagement to push companies to pursue environmental and social initiatives that are in the company's long-term interest.54 These proponents of social responsibility not only include

47 See supra note $X$.

48 Elhauge, supra note 8.

49 Fink, A Sense of Purpose, supra note 11; Fink, Purpose \& Profit, supra note 11.

50 Business Roundtable Letter, supra note XX.

${ }_{51}$ See supra note XX.

52 Of course, this is not a novel observation - for many years, people have observed that regulation or taxation is necessary to induce individuals and companies to internalize externalities created by their conduct. See, e.g., William J. Baumol, On Taxation and the Control of Externalities, 62 Am. Econ. Rev. 30, 307 (1972), and more recently, Michael Simkovic, Limited Liability and the Known Unknown, 68 Duke L. J. (2018).

53 There is an extensive literature discussing the supposed problem of market short termism. See, e.g., Mark Roe, Stock Market Short-Termism's Impact, ECGI Working Paper, https://papers.ssrn.com/sol3/papers.cfm?abstract_id=3171090 (citing papers).

${ }_{54}$ Condon, supra note 36; Michal Barzuza et al., Shareholder Value(s): Index Fund Activism and the New Millennial Corporate Governance, 93 SOUTHERN CAL. L. REV. (forthcoming 2020), https://papers.ssrn.com/sol3/papers.cfm?abstract_id=3439516. 
so-called permanent capital-mutual funds and pension funds-but also investors with more limited time horizons. As an example of the latter, the hedge fund Jana has raised capital for a fund that will focus on environmental and social activism that also creates value for shareholders. 55 The fund's first initiative pushed Apple to develop tools to minimize the harm to children from using iPhones and iPads.56

In sum, corporate law already encourages wealth-maximizing choices; if management is operating under the wrong time horizon or risk profile, shareholders can use voting and engagement to influence management decisionmaking.57 The more interesting question is whether corporate fiduciaries will make "public-interested" decisions. By public interested, I mean decisions that are clearly not wealth-maximizing; in other words, choices that would shift profits from shareholders toward employees, consumers, the environment, or the broader community. In the sections that follow, I show why the typical corporation will very rarely, if ever, make publicinterested choices, even if this is what a large portion of their shareholders desire. 58 And this reality holds regardless of what the law requires of corporate fiduciaries:59 market forces, bolstered by state corporate law and the good governance movement, push corporations to maximize shareholder wealth regardless of the legal default. In the sections that follow, I'll highlight three of these market forces: 1) takeover markets, 2) shareholder activism, and 3) executive compensation.

\section{A. Takeover Markets}

If management routinely sacrifices profits to pursue prosocial goals, the company may become a takeover target by an acquirer who can shift the direction of the company and monetize those profits for themselves. The logic is straightforward: Routine profit sacrificing will dampen the company's share price, providing an opportunity for a hostile acquirer to purchase control. By changing the direction of the company, the hostile acquirer can monetize those gains.

55 David Benoit, Wall Street Fighters, Do-Gooders-and Sting-Converge in New Jana Fund, WALL STREET J., https:/www.wsj.com/articles/wall-street-fighters-do-goodersand-stingconverge-in-new-jana-fund-1515358929 (last updated Jan. 7, 2018, 4:10 PM). Jana has since delayed the opening of its social impact fund and instead announced that it will raise socially responsible co-investments in three to five target companies. See https://www.barrons.com/articles/jana-partners-activist-investor-fund-51559837142. This co-investment model indicates that the activism that the hedge fund intends to engage in is consistent with a profit-maximizing strategy. $56 \mathrm{Id}$.

57 That is not to say that more should not be done to encourage a long-term perspective. For one, the SEC could mandate sustainability disclosure, as Jill Fisch and Cindy Williams, and separately, Ann Lipton, have urged it to do. Letter from Cynthia A. Williams, Osler Chair in Bus. Law, York Univ., \& Jill E. Fisch, Saul A. Fox Distinguished Professor of Bus. Law, Univ. of Pa. Law Sch., to Brent J. Fields, Sec'y, Sec. and Exch. Comm'n (Oct. 1, 2018), https://www.sec.gov/rules/petitions/2018/petn4-730.pdf; see also Jill E. Fisch, Making Sustainability Disclosure Sustainable, 107 GEO. L. REv. 923 (2019); Ann M. Lipton, Not Everything Is About Investors: The Case for Mandatory Stakeholder Disclosure, YALE J. ON REG. (forthcoming), https://papers.ssrn.com/sol3/papers.cfm?abstract_id=3435578. Companies could also be required to disclose practices that affect employees. See Strine, supra note 20.

${ }_{58}$ Cf. Lance Moir \& Richard J. Taffler, Does Corporate Philanthropy Exist? Business Giving in the Arts in the U.K., 54 J. BUS. ETHICS 149, 156 (2004) (analyzing gifts to the arts by 60 firms and finding that they were justified almost entirely by profit maximization).

59 See Gordon Smith, supra note 16 (arguing that "the shareholder primacy norm is nearly irrelevant to the ordinary business decisions of modern corporations" and that the norm is "one of the most overrated doctrines in corporate law"). 
This is not a novel observation. Andrei Schleifer and Larry Summers, Oliver Hart and Luigi Zingales, and Einer Elhauge all discuss the role of takeover markets in incentivizing management to make antisocial choices. Specifically, Schleifer and Summers show how a hostile bidder can take control of a company and profit by shifting value away from employees by renegotiating employment contracts.60 Elhauge,61 as well as Hart and Zingales,62 show how collective action problems encourage even prosocial shareholders to tender to hostile acquirers with antisocial goals. Even if a shareholder prefers not to tender to the hostile acquirer that plans to convert a public interested company into a profit maximizing one, that shareholder will understand that other shareholders are likely to tender. Therefore, even that prosocial shareholder will be compelled to tender for fear of losing out on the takeover premium offered by the hostile acquirer.

However, the risk of a hostile takeover is more limited than it once was. Most states offer antitakeover statutes which provide companies the ability to protect themselves from the risk of a hostile acquisition.63 Not only that, hostile takeovers are an expensive, and so not every instance of profit sacrificing is likely to subject the company to takeover risk.64 However, hedge fund activism is a more potent threat, as will be discussed in the next section.

\section{B. Hedge Fund Activism}

For companies that are unlikely to become takeover targets, hedge fund activists pose a more serious threat to management teams that sacrifice profits.65 In other words, shareholders need not tender shares to a hostile acquirer; they can simply support a hedge fund that aims to boost the stock price by pushing the company in a different direction.66 The draw for the hedge fund activist is the prospect of high returns: agitating for changes that will result in gains to shareholders will benefit the hedge fund that has taken a large stake in the company. Although the gains are shared, the risk is also lessened as the hedge fund need not take a controlling stake to succeed. All they will need to do is convince shareholders to support the campaign.

60 Andrei Shleifer \& Lawrence H. Summers, Breach of Trust in Hostile Takeovers, in CORPORATE TAKEOVERS 33 (Alan J. Auerbach ed., paperback ed. 1991).

61 Einer Elhauge, Sacrificing Profits in the Public Interest, 80 N.Y.U. L. Rev. 733, 809-10 (2005).

62 Hart and Zingales, supra note XX.

63 See Elhauge, supra note XX.

64 Monika Schnitzer, Hostile versus Friendly Takeovers, 63 Economica 37 (1996) (“"[T]he empirical evidence suggests that hostile tender offers are not very attractive. The raider has to pay for expensive advertisements and mailings to shareholders in addition to high-cost services of merchant banks and lawyers. To succeed with his offer, he often has to overcome costly takeover defenses....Furthermore, the raider typically ends up paying a high premium to shareholders.").

65 See Jeffrey N. Gordon, Addressing Economic Insecurity: Why Social Insurance Is Better Than Corporate Governance Reform, COLUM. L. SCH.: CLS BluE SKY BlOG (Aug. 21, 2019),

http://clsbluesky.law.columbia.edu/2019/08/21/addressing-economic-insecurity-why-social-insurance-is-better-thancorporate-governance-reform/ ("Today's reconcentration of ownership has invigorated the proxy battle, which can be pursued at much lower cost than a hostile bid and for which a shareholder activist bears only the risk of its toehold stake, not 100 percent ownership. The consequence is that companies have much less margin for what is perceived as strategic or operational shortfalls.").

66 See Jeff Schwartz, De Facto Shareholder Primacy, 79 MD. L. REV. (forthcoming 2020) (describing how hedge fund activism pushes companies to maximize shareholder wealth). 
Will prosocial shareholders follow suit? The calculus for them is a little different in this context, as they won't be coerced into supporting the hedge fund out of a fear of losing out on a takeover premium. Indeed, if enough shareholders are concerned about the activist investor's plans, they can freely vote no at the annual meeting. However, it is likely that many shareholders would support a plan that would result in a boost to the stock price.67 This risk has contributed to the phenomenon of companies succumbing to pressure from activists without putting the issue to a shareholder vote. 68 In the face of an activist campaign, directors will likely find it easier to agree to make changes that would move the company in a new, profit-maximizing direction rather than to fight and take the risk of an unfavorable shareholder vote.

Etsy provides an example of this dynamic at work. Etsy was founded in 2005 and from the start advertised that it sought to benefit "buyers, sellers, staff and the planet." 69 The company prided itself on treating employees well, offering generous parental leave, as well as free organic food and yoga classes. The company also prioritized the well-being of the artisans who sold goods through the site, without pushing them to maximize revenue or sales. As a result of these practices, the company was certified by non-profit B Lab as a company that met particularly high social and environmental standards. 70

But the company needed money to grow, and so it accepted millions of dollars from venture capitalists. In exchange, those venture capitalists secured board seats to ensure that they would be able to influence the company's direction.71 Seeking an exit, the venture capitalist investors pushed Etsy to go public. Immediately following the company's IPO, the company's failure to turn a profit became a focus for some of the company's new investors. Despite the company's B Corp status, a hedge fund activist bought a large stake in the company and began to agitate for changes.72 Before long, private equity firms also amassed stakes in the company. As the conflict between investors

67 See Hart \& Zingales, supra note 8 ("The support that activists rely on often comes from institutional investors who may believe that they have a fiduciary duty to their shareholders to vote for value-maximizing actions. Thus institutions may support an activist who wants to turn a clean company into a dirty one even if most shareholders are against this."). Hart \& Zingales believe that a broader articulation of institutional investor fiduciary duty-one that allowed them to maximize investor welfare not wealth — would enable institutional investors to stand up to activists. Id. But I doubt this would make a difference. For one, institutional investors are bound to act in the best interests of their investors. See SEC rules/DOL rules. That duty could be construed as supporting a course of action that is not wealth-maximizing but that a majority of investors prefer, especially given that management often provides a rationale for a vote against couched in wealth-maximization terms. Therefore, it is unlikely that an institutional investor that refused to support a hedge fund activist would run into any legal trouble. Indeed, studies of mutual fund voting show that funds are already very likely to support management in proxy contests. See Alon Brav et al., Picking Friends Before Picking (Proxy) Fights: How Mutual Fund Voting Shapes Proxy Contests (ECGI Working Paper Series in Fin., Working Paper No. 601/2019, 2019), https://papers.ssrn.com/sol3/papers.cfm?abstract_id=3101473. 68See generally Melissa Sawyer et al., Sullivan \& Cromwell LLP, Review and Analysis of 2018 U.S. Shareholder Activism, HARV. L. SCH. F. ON CORP. GOVERnANCE \& Fin. REG. (Apr. 5, 2019), https://corpgov.law.harvard.edu/2019/04/05/review-and-analysis-of-2018-u-s-shareholder-activism/ (showing the frequency with which activist hedge fund campaigns are settled).

69 David Gelles, Inside the Revolution at Etsy, N.Y. TIMES (Nov. 25, 2017), https://www.nytimes.com/2017/11/25/business/etsy-josh-silverman.html.

70 Id. For an overview of the B Corp certification process, see http://digitalcommons.law.seattleu.edu/cgi/viewcontent.cgi article=2398\&context=sulr.

71 Id.

72 Id. 
and management grew, the board of directors decided to fire the company's CEO and replace him with someone who would better carry out the activist investors' goals: increased operational efficiency and profitability.73 The new CEO allowed the company's B Corp certification to lapse, began putting pressure on sellers, and eliminated many of the generous workplace perks. 74

In this example, the company didn't wait to take the temperature of its shareholders before changing directions. The pressure from activist investors was enough. This example also shows that having legal discretion to sacrifice profits is not dispositive. Etsy had advertised to investors that it planned to look out for its employees and the sellers that used its online marketplace. But having discretion to make profit sacrificing choices is irrelevant if vocal investors are unhappy about that course of action. In this situation, the board of directors realized that in order to avoid a costly and distracting proxy fight, it would need to accede to investor demands and put their interests first.75

This and the previous section show what is likely in store for management that routinely sacrifices corporate profits. It is not that they are likely to go out of business, as others have claimed.76 Instead, they are likely to remain in business, but under someone else's control. As such, they will not routinely engage in profit sacrificing to benefit the public, even if this is what some_-or many_-shareholders desire.

\section{Executive Compensation}

Not every firm is a potential takeover target, and not every profit-sacrificing decision will attract attention from hedge fund activists. But another market force operates to keep management focused on shareholder value-executive compensation.

Most executives have their pay tied to the company's stock price. A so-called "equity-based" compensation strategy is thought to align management and shareholder incentives and usually comes in the form of stock options or stock grants.77 But equity compensation can distort incentives, such as by motivating stock buy-backs and a short-term mindset. A related problem is that compensating executives primarily with stock options means they will be unlikely to take action that will sacrifice profits and thus reduce their salary. Therefore, whenever compensation strategies tie executives' incentives to stock price, management will have incentives to boost the company's value rather than make public interested decisions.

Compounding this reality is the fact that a dampened stock price is also likely to negatively affect executive reputation and advancement. In theory, making public-interested choices could improve executive reputation. For example, the CEO that engages in public interested profit

73 Id.

74 Id. Note that as of 2017, there were no publicly traded benefit corporations. See Michael Dorf, Assessing the Assessment, 40 Seattle University L. Rev. (2017).

75 A similar phenomenon took place at Warby Parker-when it went public, it let its B Corp. certification lapse rather than comply with a requirement that it reincorporate as a benefit corporation under state law.

76 See Richard A. Posner, Economic Analysis of Law 436 (9th ed. 2014); J.B. Heaton, Leo Strine's Corporate

Decline Problem, The CLS Blue Sky Blog (Nov. 8, 2019), http://clsbluesky.law.columbia.edu/2019/11/08/leo-

strines-corporate-decline-problem/.

77 See Lucian Bebchuk \& Jesse Fried, Pay Without Performance (2004). 
sacrificing might get favorable attention from the media, stakeholders, and the surrounding community.78 That attention could help insulate the CEO from removal.79 On the other hand, the CEO who sacrifices profits for social good will have to account to shareholders and the board of directors for the decline in stock price or slower rate of growth. This could cause the board of directors to suffer negative consequences, too.80 As such, the CEO is unlikely to sacrifice profits, and if she does, she is likely to be removed. In fact, recent study shows that CEOs that invest in social responsibility initiatives that correspond with a fall in stock price 81 are $84 \%$ more likely to be fired than their counterpart CEOs that do not invest in social responsibility initiatives. 82

In sum, the CEO that makes public-interested decisions will not only make less money,83 but will also be at a greater risk of displacement - at the hand of their investors, or even their own board of directors.

The previous three sections demonstrated why the typical widely held public company is very unlikely to sacrifice profits in the public interest. Doing so would subject management to takeover threats, shareholder activism, and reputational and financial consequences. As the Etsy example reveals, this is true even if the company takes steps to advertise its alignment with a broader set of stakeholders.84 Put simply, giving management the discretion to prioritize prosocial goals that sacrifice shareholder wealth will not change the practical operation of most companies so long as the incentive structure remains the same. If we want to see companies making public interested decisions, more would need to change. The next Section explores possibilities.

\section{Corporate Social Responsibility Bonds}

What possibilities remain for proponents of corporate social responsibility, in a world of imperfect regulation? One course of action would to borrow from the activist investor playbook, but with a different endgame. Instead of agitating for structural changes that would improve accountability to shareholders - dismantling poison pills and de-staggering boards, to take two examples - activists seeking to further stakeholder objectives could push for structural changes that would insulate fiduciaries and therefore give them greater ability to sacrifice profits in pursuit of social goals. For example, stakeholder activists could push companies to adopt anti-takeover

78 Diego Prior et al., Are Socially Responsible Managers Really Ethical? Exploring the Relationship Between Earnings Management and Corporate Social Responsibility, 16 CORP. GOVERNANCE 160 (2008).

79 Id.

${ }_{80}$ Cf. Eugene F. Fama \& Michael C. Jensen, Separation of Ownership and Control, 26 J. L. \& Econ. 301, 315

(1983) ("outside directors will monitor the management that chooses them because outside directors have incentives to develop reputations as experts in decision control").

81 Tim Hubbard, Higher Highs and Lower Lows: The Role of Corporate Social Responsibility in CEO Dismissal, Strategic Management Journal (2019).

82 However, engaging in profit-maximizing CSR helps insulate the CEO. Id.

83 Some companies are beginning to tailor executive compensation to encourage prosocial goals. See note XX supra. 84 See also Michael Dorff, Assessing the Assessment, Seattle L. Rev. (describing typical legal safeguards protecting B Corps as "toothless"). 
provisions, staggered boards, anti-activist poison pills, 85 and dual class voting structures.86 Stakeholder activists could also demand governance changes that would render fiduciaries sensitive to a broader set of interests, such as by benchmarking compensation to environmental hurdles. 87

Another approach for stakeholder activists would be to seek governance rights for corporate constituents other than shareholders. For example, a company could issue preferred stock with super voting shares to employees, or give employees the right to elect a minority slate of directors. 88 Providing employees with a right to elect directors would force fiduciaries to take their interests into consideration. 89 However, this solution would only encourage decisionmaking along one additional dimension; environmental concerns, or other issues affecting broader community, might not be addressed. Not only that, studies of co-determination systems in other countries have identified problems with allowing employees control rights, including less fluid decisionmaking.90 This may be why no U.S. firms have initiated these specific changes91 (although the U.S. does have a large and growing population of worker-owned companies92).

Given the growth of social responsibility investing, it is somewhat puzzling that investor activism about environmental and social (E\&S) issues has been so limited. Yes, investors have brought non-binding shareholder proposals in an attempt to nudge companies to improve their disclosure of environmental risks or disclose corporate political spending payments, to take two

85 Marcel Kahan \& Edward Rock, Anti-activist Poison Pills, 99 B.U. L. REV. 915 (2019).

86 Marty Lipton has pushed for such reforms for decades, and continues to do so today. See, e.g., Martin Lipton et al., It's Time to Adopt the New Paradigm, https://corpgov.law.harvard.edu/2019/02/11/its-time-to-adopt-the-newparadigm/; Martin Lipton, Takeover Bids in the Target's Boardroom, 35 BuS. LAW. 101, 104 (1979).

87 Robert Newbury et al., Willis Tower Watson, Compensation Committees \& ESG, HARV. L. SCH. F. ON CORP. GOVERNANCE \& FIN. REG. (Aug. 31, 2019), https://corpgov.law.harvard.edu/2019/08/31/compensation-committeesand-esg/; https://corpgov.law.harvard.edu/2019/11/29/performance-metrics-accelerating-the-stakeholdermodel/\#more-124425.

88 This is the sentiment behind Elizabeth Warren's proposed legislation that would give employees the right to elect two out of five directors. S. 3348, 115th Congress (2018), as well as Leo Strine's proposed legislation that would implement European-style workers' councils. See note XX.

89 See Gary Gorton \& Frank Schmid, Class Struggles Inside the Firm: A Study of German Codetermination (NBRE Working Paper Series, Working Paper No. 7945, 2000), https://www.nber.org/papers/w7945.pdf ("We find, in fact, that co-determination does empower employees, and that they use their power in ways that contradict the desires of shareholders, that is, they change the objective function of the firm.")

90 Id.; Elmar Gerum \& Helmut Wagner, Economics of Labor Co-determination of Corporate Governance (unpublished manuscript), https://www.researchgate.net/publication/228322896_Economics_of_Labor_CoDetermination_in_View_of_Corporate_Governance (summarizing other empirical findings, including inefficient decision-making). Unsurprisingly, scholars also show that companies with co-determination have reduced profitability. Id.; Gary Gorton \& Frank A. Schmid, Capital, Labor, and the Firm: A Study of German Codetermination, 2 J. EuR. ECON. Ass'N 863 (2004).

91 Michael C. Jenson \& William H. Meckling, Rights and Production Functions: An Application to Labor-managed Firms and Codetermination, 52 J. Bus. 469 (1979).

92 The Employee Ownership 100: America's Largest Majority Employee-Owned Companies, NCEO (July 24, 2019), https://www.nceo.org/articles/employee-ownership-100; Peter Walsh et al., Why the U.S. Needs More WorkerOwned Companies, HARVARD BuS. REVIEW (Aug. 8, 2019), https://hbr.org/2018/08/why-the-u-s-needs-moreworker-owned-companies. 
examples.93 Other investors have done more. For example, State Street has promised to withhold votes for nominating directors that serve on all-male boards.94 Likewise, BlackRock has promised to engage with companies until they produce a clearly defined purpose that serves society. 95 The hedge fund Jana at one point even promised to launch a fund focused on socially responsible investing (it has since delayed the launch).96 These are all laudable efforts, but are far less radical and influential than initially appears. For one, all justify their advocacy as maximizing long-term shareholder wealth.97 More important, none move the power structure of the corporation away from shareholders and toward other groups - management or even employees - in the way that is necessary to encourage public-interested decisions.

We should not be surprised that major investors - most of whom are investment intermediaries that are fiduciary duty bound to act in their investors' best interests98 - aren't using activism to move companies away from a shareholder wealth-maximization viewpoint. In fact, they have been most influential in taking steps to increase management's focus on shareholder interests, including by demanding equity-based compensation, unified boards, and single-class equity structures.99

In other words, radical change is unlikely to come from shareholders themselves. In addition, were companies to enact the changes necessary to allow fiduciaries to freely make public interested decisions, the ensuing lack of accountability could lead to other problems - most notably, increased managerial agency costs.100 Indeed, governance reforms of this kind cut against decades of good governance advocacy designed to empower shareholders and ensure that management teams remain accountable to them.101 And it is possible that some management teams would use their discretion to slack or maximize their private benefits, leading to economic harm-if not now, then at some time in the future. 102

93 See Subodh Mishra, Institutional Shareholder Services, Inc., An Early Look at 2019 US Shareholder Proposals, HARV. L. SCH. F. ON CORP. GOVERnANCE \& FIn. REG. (Mar. 5, 2019),

https://corpgov.law.harvard.edu/2019/03/05/an-early-look-at-2019-us-shareholder-proposals/.

94 See Barzuza et al., supra note 54.

95 Fink, A Sense of Purpose, supra note 11.

96 See supra note XX.

$97 \mathrm{Id}$.

98 SEC Rule/DOL rule; see also Hart \& Zingales supra note XX.

99 BLACKRock, PROXY Voting GUIDELINES FOR U.S. SECURITIES (2019),

https://www.blackrock.com/corporate/literature/fact-sheet/blk-responsible-investment-guidelines-us.pdf (embracing shareholder responsiveness, unitary boards, majority voting, equal voting rights, and opposing poison pills); https://www.ssga.com/our-insights/viewpoints/2019-proxy-voting-and-engagement-guidelines-northamerica.html (embracing shareholder rights, majority voting, annual elections, proxy access for shareholders, and opposing poison pills); VANGUARD, VANGUARD FundS PROXY VOTING GUIDELINES FOR U.S. PORTFOLIO COMPANIES (2019), https://about.vanguard.com/investment-stewardship/portfolio-company-

resources/proxy_voting_guidelines.pdf (opposing limited shareholder rights, unequal voting rights, and defensive structures, embracing pay-for-performance equity compensation, unified boards, majority voting); see also Ian Appel et al, Passive Investors, Not Passive Owners, Journal of Financial Economics (2016) (showing that a higher percentage of passive fund ownership is associated with a firm being less likely to have unequal voting rights, takeover defenses, and classified boards); Eli Kasargod-Staub, Majority Action, Climate in the Boardroom, HARV. L. SCH. F. ON CORP. GOVERNANCE \& FIN. REG (Oct. 7, 2019), https://corpgov.law.harvard.edu/2019/10/07/climatein-the-boardroom/ (showing that the Big Three rarely support ESG shareholder proposals).

100 See supra note XX.

101 See Lund and Pollman, supra note Error! Bookmark not defined.

102 See Fried, supra note 14 ("If the Business Roundtable CEOs really were able unilaterally to disempower shareholders, the economy would suffer. Excess capital would be trapped inside their companies because managers 
Is there any hope for people who hope to encourage corporations to make public interested decisions? This Article proposes a way forward that works within the wealth maximization framework, and yet could result in dramatic social change. The idea is simple: use private markets to provide incentives for corporations to make public interested decisions. One promising option, which the remainder of this article will focus on, would be to issue "corporate social responsibility bonds." 103 These pseudo-bonds, pseudo-donations would allow people to finance the company's pro-social future. The intuition is as follows: if it is welfare-maximizing for individuals to see corporations make public interested choices, there should be a possible Coasian bargain between the individuals who desire the public interested choice and the corporation. These individuals might include the company's shareholders, but more likely, they will be entities or individuals external to the corporation, such as pension funds, other institutional investors, charitable organizations, foundations, university endowments, and nonprofits.

How would these corporate social responsibility bonds work? The issuer (likely a non-profit) would first identify a public interested corporate decision-something that would have a large positive impact on employees, consumers, communities, or the environment - that is not wealthmaximizing for the company. The issuer would then raise money to support that decision by issuing a bond, describing in a detailed offering document how the company would use funds to implement the decision and why they would not otherwise make it without investment. Individuals could invest, earning interest for as long as they waited for the project to be implemented. If the company agreed to implement the decision, the nonprofit would loan the money to the company using a promissory note. If the project was implemented according to the offering document, the loan would be forgiven. If it was not, the investors would get their money back plus interest.104

Therefore, the corporate social responsibility bond is a tool that could motivate real corporate change, without any government intervention. It would provide an opportunity for philanthropic individuals who dedicate $2 \%$ of GDP to charitable giving each year to use their money to direct corporate decisionmaking.105 And by working within the existing wealth maximization framework, the corporate social responsibility bond would avoid the risks to managerial accountability that would come from abandoning shareholder primacy altogether.

In the sections that follow, I describe in further detail the concept of a social responsibility bond. I begin by exploring examples of how they might be used, and then set forth some of the attenuating issues and difficulties. I conclude by demonstrating that this instrument, although novel, has its origins in recently developed financial instruments aimed at uniting prosocial investors and profit-maximizing companies.

\section{A. Corporate Social Responsibility Bonds: The Possibilities}

prefer to play with more money. Resources would be mis-invested. If payouts from public companies declined, unlisted firms would have less access to capital. Furthermore, investors might think twice before investing in a small, growing company. If it fails or goes sideways, they lose. If it goes public, its CEO might decide to use its assets to serve all manner of stakeholders, with shareholder returns as an afterthought.").

103 Other possibilities are explored infra Section XX.

104 In order to preserve deductibility, the investors would need to specify that the donation would roll-over if the bond fails. See supra note XX.

105 James Andreoni et al, supra note XX. 
This section provides examples of where corporate social responsibility bonds could be used to great effect. Note that in each example, a bond is used to push the company to make a choice that is not-wealth maximizing (and therefore will not be made without external pressure), but that would result in major societal benefits. In addition, these examples are unlikely to be addressed by government regulation, nor are they likely to be addressed as a result of pressure from consumers, shareholders, and employees. In the sub-sections that follow, I describe three ways that these bonds could generate large social benefits: by 1) encouraging decisions with beneficial secondary effects, 2) helping overcome coordination costs, and 3) supporting a decision in which the marginal return from corporate philanthropy is higher than individual philanthropy.

\section{i. $\quad$ Beneficial Secondary Effects}

At its best use, a bond could be used not just to alter practices at the underlying company, but also to transform the entire industry. The introduction considered the example of the power plant and scrubbers that would cost $\$ 150$ million, but would result in secondary societal benefitsincluding by easing the prospect of industry-wide regulation. As another example, consider how a bond could be used to transform supply chains for the better. Every year, McDonalds buys 3.4 billion pounds of potatoes - approximately 7\% of U.S. production. 106 Therefore, the company has the ability to alter supply chain dynamics as a buyer. Suppose that the cheapest option for the company is a potato farmed using pesticides that harms the environment and consumers, but is nonetheless legal. In addition, consumers are not sufficiently aware of or bothered by the risks to alter their consumption. The cost of an organic pound of potatoes would be 7 cents, or $10 \%$ more than the non-organic pound - for an annual total of \$240 million. Of course, McDonalds will not buy the organic potatoes, even though doing so would benefit consumers and the environment.

What would happen if a corporate social responsibility bond was used to push McDonalds to buy organic potatoes? Because McDonalds is such a large buyer, the increased demand could further drive up prices for organic potatoes temporarily, inducing other farmers to grow them. If this happened, prices could eventually fall-perhaps not to the level of non-organic potatoes, but below the initial price of 7 cents per pound. These price effects could induce other companies to buy organic potatoes. Indeed, McDonalds' compliance with the developing norm could encourage other companies to follow suit in another way: McDonalds would likely advertise that it is using organic potatoes, which could put pressure on other fast-food restaurants to change course. Eventually, therefore, the bond could cause the equilibrium to shift by increasing both supply and demand for organic potatoes.

As another example, corporate social responsibility bonds could also be used to benefit workers by convincing an industry leader to change its practices. Take the following example: Nike, like many global retailers, utilizes overseas sweatshops to produce sneakers. As a result of consumer boycotts, Nike has improved conditions somewhat, but overall conditions remain dismal. Let's assume that the cost of bringing these overseas factories into compliance with OSHA standards would be $\$ 100$ million; therefore, Nike is unlikely to do so. Consumer pressure is unlikely to move the needle; indeed, consumers might not even be aware of the conditions in

106 John Miller, McDonald's Fries the Holy Grail for Potato Farmers, SPOKESMAN-Rev. (Sept. 23, 2009, 9:44 AM), https://www.spokesman.com/stories/2009/sep/23/mcdonalds-fries-holy-grail-potato-farmers/. 
overseas factories. Not only that, regulation addressing overseas factory conditions is unlikely to be forthcoming, and even if a country was to adopt more stringent regulation, Nike could move its factory elsewhere. In this situation, the use of a corporate social responsibility bond might be the only way to incentivize the company to improve worker conditions. And as in these other examples, were Nike to participate and advertise its compliance, it would focus attention on other companies that failed to enact the same changes.107 Not only that, targeting Nike - an industry leader - might remove opposition from that company to regulation that would bind rivals, easing the prospect of industry-wide regulation.

Finally, a bond could be used to encourage a company embark on a new project with large social benefits. Consider Bombay Dyeing, 108 one of the largest global textile manufacturers, which primarily uses polyester and cotton yarns used by clothing manufactures. These fabrics have increasingly come under scrutiny from researchers and non-profits for their harmful environmental impact.109 A corporate social responsibility bond could be used to push Bombay Dyeing to instead produce new sustainable fabrics. As one example, consider fabric made from banana fiber, which is nearly carbon neutral.110 But assume that the cost of producing this fabric is prohibitively expensive without economies of scale and expertise in the textile industry. Imagine that it would cost \$500 million dollars for Bombay Dyeing to launch a new fabric line using banana fiber technology, and that customers would be unwilling to bear the costs in the form of higher prices for banana fiber clothing. As such, the company will not move from the status quo. However, were it to do so, and invest in the infrastructure necessary to produce banana leaf fabric at scale (which would include investments in suppliers and marketing), the cost would be the same for the company as producing cotton in future years. By encouraging an investment in sustainable fabric production and kickstarting a green fabric market, the corporate social responsibility bond could transform the textile industry.

\section{ii. Overcoming Coordination Costs}

Bonds could also overcome coordination costs for individuals who may value public interested corporate action but that are unable to identify other likeminded individuals or the course of action that would result in the desired change.111 For example, Wal-Mart is one of the biggest sellers of guns in the world.112 Let's suppose that the company does not generate much revenue from these sales, but it expects that were it to stop selling guns, it would be subject to boycotts that would reduce revenue by $1 \%$--for a total of $\$ 5$ billion, or $\$ 300$ million in lost EBITDA.113 Assume also

107 However, Nike might be concerned that the bond would have the opposite effect—shine a spotlight on the company's harmful practices, which would hurt its brand and reputation. That concern might chill Nike from accepting to work with a bond issuer in the first instance. For a discussion of this concern, see Section XX supra. 108 BOMBAY DYEING, https://bombaydyeing.com/ (last visited Nov. 11, 2019).

109 Environmental Impacts, Green Choices, https://www.greenchoices.org/green-living/clothes/environmentalimpacts (last visited Nov. 11, 2019).

110 FASHIONUNITED, https://fashionunited.uk/news/fashion/sustainable-textile-innovations-bananafibre/2017082825623 (last visited Nov. 11, 2019).

111 Relatedly, bonds could induce companies to produce companies to bundle altruism with other goods and therefore reduce free riding. See Todd Henderson and Anup Malani,

https://chicagounbound.uchicago.edu/cgi/viewcontent.cgi?article=8004\&context=journal_articles

112 Chris Isadore, What Would Happen if Walmart Stopped Selling Guns, CNN: BuS.,

https://www.cnn.com/2019/08/05/business/walmart-gun-sales/index.html (last updated Aug. 6 2019, 11:30 AM).

113 Walmart 10K. 
that there would be a boost in sales from anti-gun consumers, but that this boost would only result in $\$ 150$ million in additional earnings. Therefore, Wal-Mart continues to sell guns and ammunition, even in the face of pressure from consumers and anti-weapons activists.114

What options remain for the diffuse body of individuals who are opposed to this practice? An individual would likely feel powerless to make a change. Of course, gun control nonprofits could serve as a coordinating mechanism for diffuse individuals. But these individuals might be wary to donate if they are unsure of whether the organization's efforts will be successful. For example, suppose a gun control organization promises that all donations will be used to fund lobbyists that would urge gun control efforts by retailers. A donor might correctly perceive that whenever lobbying tries to change the status quo, successes are quite rare.115 In addition, lobbying resembles an all-pay auction, in which the lobbyist with the highest expenditure is certain to win.116 This means that if another group spends a single dollar more, all expenditures by the nonprofit will have been in vain.117 This provides a disincentive to participate at all, especially when success is unlikely.

But what if the nonprofit instead promised that it would use the donated funds to support a corporate social responsibility bond that would change the calculus for the Wal-Mart? Offering to offset the costs of the decision might actually induce Wal-Mart to stop selling guns.118 In other words, the non-profit's decision to use a bond might overcome coordination costs of dispersed individuals who value the course of action. From a social welfare perspective, the bond would more efficiently accomplish the intended goal than lobbying, which entails waste whenever two sides conflict over a given course of action and are induced to spend vast sums to win.119 And as in the previous examples, altering the practices of this major gun retailer could have beneficial secondary effects, including by influencing other big-box weapons retailers to stop offering guns. Even if Wal-Mart was the only retailer to change course, the reduced availability of guns from a single major retailer would likely decrease the risk of gun violence. 120

\section{iii. Higher Marginal Return from Corporate Philanthropy}

114 Dick's Sporting Goods stopped selling guns and faced similar boycotts. But those boycotts were offset by a rise in sales from customers who approved of the decision. Id.; Joe Williams, Dick's Sporting Goods Admits Suffering Gun Policy Backlash as Sales Slide, WASH. EXAMINER (Nov. 28, 2018, 10:56 AM), https://www.washingtonexaminer.com/business/dicks-sporting-goods-admits-suffering-gun-policy-backlash-assales-slide.

115 Kathleen Marchetti, You Don’t Know Jack: Principals, Agents, and Lobbying, https://www.researchgate.net/profile/Kathleen_Marchetti/publication/263328149_You_don\%27t_know_Jack_Princi pals_agents_and_lobbying/links/552fc7050cf2f2a588a9b2f5.pdf

116 Hanming Fang, Lottery versus all-pay auction models of lobbying, 112 Public Choice 351 (2002).

117 Cf. Tullock, G. (1980). Efficient rent seeking.

118 A weaker version of the bond would require Wal-Mart to implement background checks and/or stop selling certain types of weapons. These decisions would be unlikely to generate the same blowback, so would be cheaper for investors to implement. However, they might not be as effective at reducing gun sales; therefore, it could be more difficult to raise money to fund the bond.

119 See Tullock, supra note XX. Of course, people who were opposed to the Wal-Mart bond could fund a rival bond that would urge Wal-Mart to keep guns on the shelves. However, unlike lobbying, social responsibility bonds require transparency and operate out in the open, perhaps making them less appealing.

120 There is a link between availability of guns and the incidence of mass shootings. Paul M. Reeping et al., State Gun Laws, Gun Ownership, and Mass Shootings in the U.S.: Cross Sectional Time Series, THEBMJ (Mar. 6, 2019), https://www.bmj.com/content/364/bmj.1542. 
In certain instances, corporate philanthropy will offer individuals a higher marginal return than individual philanthropy aimed at accomplishing the same result.121 That is because it may be very expensive for individuals to undo the harmful effects of corporate actions. For example, Harley Davidson plans to move plants overseas to avoid new tariffs imposed on U.S. manufacturers.122 The company estimates that the new tariffs would cost the company $\$ 90$ million each year, but the move overseas is predicted to cost 10,000 American workers their jobs. Let us also assume that most of those workers would not find new jobs and would therefore become unemployed.

If Harley Davidson moved the factories, it would be extremely costly for individuals to offset the damage. They would have to identify the unemployed individuals, find new jobs paying the same wage in the same area, and possibly invest in training so that the employees would be qualified for these jobs. It might not be possible for individuals to do this, and even if they could, it would likely be prohibitively expensive.

By contrast, a bond that urged Harley Davidson to keep the jobs in the United States would offer a much higher return on investment. Consider how this might happen: a workers' rights nonprofit, such as Jobs With Justice, 123 could solicit a bond that would offset the costs of the tariffs for the company. It could negotiate with the company on the ultimate price, ultimately arriving at a sum less than $\$ 90$ million because taking the expensive course of action would result in offsetting reputational benefits and save on costs associated with moving production.124 Perhaps they would split the difference and the company would agree that an investment of $\$ 45$ million would be enough to keep the jobs in the United States. The nonprofit would then solicit investment for the bond - from philanthropic shareholders and other individuals, foundations, and workers' rights groups. If the bond was funded, the company would be required to keep the jobs domestically or lose the money, and the optics of turning down the money would make the latter approach particularly unappealing.

* $\quad * \quad *$

These examples show how corporate social responsibility bonds could be used to alter corporate decisionmaking when the social welfare benefits are great. And it does this without requiring any legal change; we need not wait for Congress, or even the states, to alter the legal obligation of corporate fiduciaries, adopt corporate externality regulation, or provide new legal rights to third parties. The corporate social responsibility bond could be used to affect corporate deicisonmaking without delay.

121 See also Hart \& Zingales, supra note XX (stating that "Friedman's separability assumption requires consumers to have a (scalable) project that is the reverse of the project implemented by the corporation. But is there any reason to think that the reverse of an oil digging project, say, always exists? In many cases this would seem to defy belief."). 122 Carson Kessler, Why Harley-Davidson Is Moving Production Overseas, FORTUNE (June 26, 2018), https://fortune.com/2018/06/26/harley-davidson-moving-production-overseas/.

123 JOBS WITH JUSTICE, https://www.jwj.org/ (last visited Nov. 11, 2019).

124 The introduction of a monetary payment for the decision could somewhat reduce the altruistic signal and corresponding reputational boost from the decision, but it is unlikely to eliminate it. Roland Bénabou, \& Jean Tirole, Incentives and Prosocial Behavior. 96 AM. ECON. REV. 1652, 1652-78. 
Not only that, the corporate social responsibility bond works within the wealth-maximization framework. Therefore, it induces prosocial decisions without leading to the problems that economists and legal scholars predict would manifest if fiduciaries were no longer bound to maximize shareholder wealth, including increased agency problems.125 There are good reasons why shareholder rights advocates have spent the past few decades seeking increased accountability to shareholders. 126

Another main advantage of a corporate social responsibility bond is that it accomplishes a wealth transfer from the people who believe that the action is welfare maximizing; individuals that do not want to pay for it don't have to. Compare this to mandating corporations to make public interested decisions, which taxes all shareholders equally, even those that disagree with the decision.127 But this reality leads to a limitation, too. Because these bonds entail a privately provided public good, free riding is very likely. If others will pay for it, why should I?

The same concern is true of all charitable giving, and yet, most households give to charity. 128 Indeed, $2 \%$ of U.S. GDP, or nearly $\$ 300$ billion, is devoted to charitable giving each year. 129 This means that there is a sizable pool of money available from individuals interested in seeing social change. Moreover, there is a palpable interest in seeing corporations change their behavior. Inflows to social responsibility investment vehicles have reached all-time highs;130 institutional investors compete by advertising their prowess on environmental, social and governance ("ESG") issues.131 People understand that corporations are powerful actors, and yet are frustrated by a lack of tools to effect change. The corporate social responsibility bond would offer donors a chance to influence corporate decisionmaking for the better, and could therefore appeal to many individuals.

\section{B. Nuts and Bolts}

How would these bonds be issued? Who would issue them? Who would buy them? The following sub-sections answer these questions.

\section{i. Initiating the Process}

In theory, the company could proactively issue a bond.132 But more likely, a third-party entity or several third-party entities would issue the bond and then work with the company to implement

125 A.A. Berle, Jr., For Whom Corporate Managers Are Trustees: A Note, 45 HARV. L. REV. 1365, 1367 (1932) ("When the fiduciary obligation of the corporate management and 'control' to stockholders is weakened or eliminated, the management and 'control' become for all practical purposes absolute.").

126 See, e.g., Lucian Bebchuk, The Case For Increasing Shareholder Power, Harv. L. Rev. (2004).

127 These shareholders include not only the wealthy, but a large percentage of ordinary Americans saving for retirement. INV. CO, INST., supra note 36 (showing that $44.8 \%$ of U.S. households invest in mutual funds). 128 Andreoni \& Payne, supra note 105.

129 Id.

130 See https://www.wsj.com/articles/top-esg-funds-are-all-still-invested-in-oil-and-gas-companies-11573468200.

131 See Barzuza et al., supra note XX.

132 This Article refers to this instrument as a "bond" because of parallels between the instrument I envision and related innovations in the socially responsible finance space, including green bonds and impact bonds. In addition, debt arrangements tend to force borrower disclosure and provide information rights to lenders, both of which would be useful in this context. See Baird and Rasmussen, supra note XX. However, it is not necessary to issue a bond-in theory, the same arrangement could be accomplished by contract, avoiding securities ramifications for the issuer. The 
it. A useful third-party collaborator could be a non-profit with experience dealing with the bond's ultimate goal: as an example, the Environmental Defense Fund could work with the coal-fired power company to issue the scrubber bond discussed in the introduction.133 One advantage of having a non-profit issue the bond is the contributions would likely be tax deductible, meaning that a $\$ 1$ of investment would cost much less.134 Public interested banking groups or family foundations could also assist: Goldman Sachs' urban development group 135 provides one example. In all likelihood, the issuance of the bond would involve several sophisticated entities.

Under certain circumstances, the third-parties might issue the bond without any involvement from the company in question. If the bond was successfully funded, the third-parties would then negotiate a loan to the company in question. The advantage of this approach is that it would increase the third-parties' leverage in negotiations: when the company is involved with creating the terms of the bond, it can more easily push for more favorable terms. By contrast, if the company is presented with the opportunity to get a loan and the ensuing terms, it will have a harder time saying no or influencing the terms in a way that is overly favorable to it. This approach would only work, however, where there are not insurmountable information asymmetries between the company and the third-parties.136 Where outsiders cannot easily estimate the cost of the decision, as well as the course of action that would correct it and the ensuing benefits, they would not be able to issue a bond without input from the company.

Assuming that the idea for the bond did not originate with the company, and was instead brought to the company's attention, would the company be receptive? On the one hand, the prospect of receiving money in the form of a forgivable loan should be attractive. On the other hand, the company might worry about agreeing to take a course of action that is patently not wealth maximizing. Although the bond purports to offset the costs associated with the decision, the company could be concerned that it will be difficult to shift gears in the future, or that the costs will be greater than estimated.

contracting counterparty could simply negotiate for a covenant stating that the loan is conditional on the underlying action being taken, and if the company breached the covenant, it would be required to return the money plus penalty interest.

133 There is a possibility that a non-profit that issued a corporate social responsibility bond would lose its tax-exempt status. Federal laws generally "deny tax exempt status to organizations that confer substantial benefits on private interests not among the charitable class."

https://ir.lawnet.fordham.edu/cgi/viewcontent.cgi?article=4910\&context=flr; see also Treas. Reg. § 1.501(c)(3)1(d)(1)(ii). However, the IRS has defined "private benefit" narrowly to include only those individuals with an interest in the organization (such as the creator of the nonprofit or its shareholders), not private individuals that are external to the organization. Treas. Reg. $\S 1.501(\mathrm{c})(3)-1(\mathrm{~d})(1)(\mathrm{ii})$. Even if the IRS was to take a broader view of the private interest test, the doctrine is likely sufficiently opaque to allow room for nonprofits to issue corporate social responsibility bonds. For example, if the private benefit from issuing the bond is incidental to a public benefit, then the nonprofit can keep its exempt status. See I.R.S. Gen. Couns. Mem. 39,598 (Jan. 23, 1987). Moreover, debt instruments are scrutinized less closely than equity instruments under the private benefit doctrine. See Michael Sanders, Joint Ventures Involving Tax-Exempt Organizations $§ 5.1(\mathrm{a})$ (3d ed. 2007).

134 See note XX supra.

135 Impact Investing, GOLDMAN SACHS, https://www.goldmansachs.com/what-we-do/investing-and-lending/impactinvesting/(last visited Nov. 11, 2019).

136 Proposals to increase ESG disclosure would help reduce information asymmetries about corporate social responsibility. See Fish and Williams, infra note XX, Lipton, infra note XX. 
The company might also worry about the optics of being paid to avoid harm. In the Nike example mentioned above, the existence of the bond would be an advertisement to the world that Nike does not treat its workers fairly, and that it will only make changes if it is paid to do so. But this optics effect depends on how the public views the corporation and its conduct. If the public perceives that is the bond induces heroic behavior-like the bounty for a whistleblower who takes great risk to report a crime - there is no shame in rewarding it. Put differently, if the public perceives that the company is departing from behavior that it has every right to engage in, the bond will appear to be just compensation for the decision to sacrifice profits. But there is a growing consensus among the public that wealth-maximization is not a desirable objective function for the firm. This may render the possibility of accepting bond money unpalatable to many companies.

Although this optics problem is a hurdle for bond proponents, the refusal to work with a nonprofit that is offering a bond could result in a different sort of reputational problem. In the latter situation, Nike is not just treating its overseas workers badly, but is refusing a large sum of money intended to correct the problem. In sum, corporate reputational effects cut in both directions.

There is also the opposite concern: not that the company would hesitate, but that it would be too willing to accept the money. Perhaps the company would be worried that if it doesn't accept the bond, a rival company will, which would increase the likelihood that the company would face pressure to make the change in the absence of a bond. Worse, a company could attempt to seek funds for actions that are wealth-maximizing. This risk is especially likely for bonds that encourage companies to take on NPV uncertain projects. For Dick's Sporting Goods, for example, the decision to stop selling firearms ended up boosting revenue.137 Ex ante, outside observers might have guessed that the decision would have the opposite effect. Given the market pressures that corporate executives face, however, the fact that these decisions are not being made indicate that they are not wealth-maximizing, at least in the near term. But this concern could chill investors from supporting bonds in many cases; in order to encourage investment, issuers will need to study the company's financial information so that they can credibly certify that the action would not be taken made without the investment.

Assuming that the corporation is a good candidate for a bond, and that the corporation is willing to issue a bond or accept the proceeds, the third-party has an additional role to play in creating the terms and monitoring the process. In addition, the third-party could also negotiate with the company to bring down the cost of the bond. Finally, the-third party would be charged with monitoring the company's compliance with the bond, easing the burden on donors. The following sub-sections contain more details about the offering terms and enforcement.

\section{ii. The Offering Document}

As the previous section indicated, the offering document would entail significant disclosure. It would describe in detail the decision that investing in the bond would encourage. The company would need to certify that, to its knowledge, the decision is not wealth-maximizing, and therefore, that the decision would not be made absent the investment. The offering document would also describe how the company would use the funds to implement the decision and how success would

137 See supra note XX. 
be measured. It would attempt to quantify the social benefits of the bond.138 And it would inform donors that if the company successfully implements the decision, the loan would be forgiven-in the meantime, the company would pay interest on the funds. The offering document would also describe the third-party's involvement_-including the negotiations and monitoring role that it would play going forward - and provide the nonprofit with necessary information rights.139

What about pricing? In theory, the total amount of money raised would offset the lost profits that would result from making the public interested decision.140 But in reality, the price could and probably should be much lower. For one, the loss in profits would likely be offset by benefitsincreased worker productivity, fewer lawsuits, reputational benefits, etc. The total amount would be difficult to quantify, and would likely vary from company to company. Second, the company that refuses to work with the non-profit could suffer a negative reputational effect. For that reason, a company may need to accept less money than it would otherwise need to offset the costs of making the decision to avoid a hit to its reputation.

To see where the pricing negotiation might end up, consider again the Wal-Mart example in Section XX. Recall that the expected cost of eliminating guns from stores was $\$ 300$ million. But the bond would not need to recoup that amount because the policy change would have an expected offsetting benefit of $\$ 150$ million. In addition, the non-profit might determine that Wal-Mart would be willing to accept a smaller amount, as it would suffer reputational consequences if it turned down a vast sum of money to end its gun sales. Indeed, the corporation could advertise the discounted bond as a form of corporate giving: it is partnering with the non-profit in question to alter its practices to benefit society. The ultimate price of the bond, consequently, might be only $\$ 100$ million.

The pricing issue is likely the most difficult hurdle that issuers of corporate social responsibility bonds will face: it will be very difficult to quantify the precise cost and benefit from any decision or set of decisions, and especially difficult for outsiders to monitor. One strategy to reduce the risk of error would be to employ a pseudo-earn-out.141 Taking the Wal-Mart example again, the company might over-estimate the cost and under-estimate the benefit ex ante. Knowing that, the third-party negotiating with the company could specify that if the cost is less and the benefit greater, donors would get a portion of their money back. In this situation, the donors would be splitting the risk created by implementing the decision with the company. This arrangement would lessen the third-party's task of estimating the cost and benefit ex ante. The problem with an earn-out, of course, is the prospect of costly negotiations later on.142 A clear description of how

138 The recently developed Impact Reporting and Investment Standards (IRIS) system, which establishes criteria for social impact investing, can help with this. See Kogut et al., supra note XX.

139 An additional advantage of issuing the bond, from the nonprofit's perspective, is that the offering document could force disclosure that would benefit the public. See Lipton, supra note XX.

140 Note that the donation would likely be taxable to the company, which would somewhat increase the cost. However, the company's tax planners could help it structure the transaction to reduce the overall tax burden. See note XX supra.

141 See Stefano Caselli et al., Managing M\&A Risk with Collars, Earn-outs, and CVRs, J. APPLIED CORP. FIN., Fall 2006, at 91 (describing the asymmetric information and moral hazard in M\&A transactions and how earn-outs can limit the effects of uncertainty and risk).

142 Jonathan I. Handler \& Jillian B. Hirsch, Developments in the World of Earn-Outs, 19 Corporate Finance Review (2014). 
the earn-out would be calculated would lessen some of this burden, as it does in M\&A transactions. 143

Another pricing complication is that some decisions do not need to be made only once, but are recurring. In the example involving McDonald's potato purchases, the company might hesitate before accepting a bond that offset expenses only for a single year. The parties could handle this issue in various ways. They could increase the price of the bond in order to induce a promise to change behavior in future years. Perhaps McDonalds would be required to pay damages to the donors if it reverted during the period of time contemplated by the parties. In the alternative, the third-party may foresee that if McDonalds makes the change for a single year, it will be difficult for it to go back to its old practices in a subsequent year. Another possibility is that if McDonalds makes the change, it will make the decision to source organic potatoes cheaper going forward. As with the previous issue, this complication will need to be handled on a case-by-case basis.

Another possibility for issuers to consider is that the activity subject to the bond could be subject to regulation after the company receives the bond proceeds. The offering document should specify in advance what would happen to the proceeds if this eventuality were to occur. But, under most circumstances, I anticipate that the company would be permitted to keep the money. At its best use, the corporate social responsibility bond would be used to alter industry standards and the regulatory environment. It would target industry leaders who would otherwise not have an incentive to choose the prosocial course of action. And offsetting the costs of compliance for the industry leader would remove a major source of opposition to the regulation, increasing the likelihood that it would occur. Indeed, the prospect of regulation would also encourage industry leaders to participate in the offering; if regulation was very likely, the company might make the decision for far less than the total cost.

As discussed, the offering document would need to certify that the decision is not wealth maximizing. But what about decisions that are wealth-maximizing in the very long-term, but profit-sacrificing in the short term? In theory, a bond could be issued to encourage these choices, too. Imagine, for example, that an investment in clean energy is likely to pay off for a coal company sixty years into the future, well beyond the current management team's tenure. Even though this choice could eventually be profitable, it is unlikely that management will make it now.144 Therefore, a corporate social responsibility bond could be used to encourage the company to make the choice today. Perhaps the bond could also provide for some donor repayment in the future, whenever the course of action becomes profitable, again using an earn-out mechanism. Another option for the issuer would be to partner with a financial investor who would be unwilling to bear a lower rate of return in the near term. The bond could cover the interest payments in the near term, enticing the financial investor to invest the necessary funds to make the choice. 145

143 Id.

144 Although in theory, a company's stock price could go up in anticipation of future profitability, the more salient effect on stock price will be many years of lower profits in the near future. See generally, Charles Wang, ShortTerm and Long-Term Market Inefficiencies and Their Implications, https://www.northinfo.com/documents/30.pdf. In addition, shareholders should be particularly skeptical of a plan that is predicted to manifest many years into the future, beyond the tenure of the current management team. Much can go wrong during that time, and the first manager will not be there to bear the consequences.

145 See Kogut et al., supra note XX. 
Similarly, a bond could be used to nudge a company that is unwilling to take on a project that is NPV uncertain. Take the Wal-Mart example once again. The decision to stop selling guns is fraught with risk for the company, which would likely result in boycotts and negative press from pro-gun groups. On the other hand, if enough shareholders and consumers rewarded the company for eliminating gun sales, the decision could ultimately increase profits. Given the uncertainty, the CEO might be wary to rock the boat without encouragement in the form of a corporate social responsibility bond. However, the prospect of moral hazard would be very great - it would be difficult for the outsider to evaluate whether the CEO was simply feigning disinterest in order to solicit bond funds. To alleviate that risk, the offering document could provide for repayment if the decision ends up being less costly than anticipated. Section III.E explores other financing possibilities for NPV uncertain projects.

\section{iii. Purchasers}

Possible purchasers of these bonds include any individual or entity for which the decision would be welfare-maximizing. According to Oliver Hart and Luigi Zingales, corporations should maximize shareholder welfare, and not wealth. 146 But if welfare is the right lens, why limit welfare to that of shareholders? Again, this is because administering a standard that encompasses multiple points of view is complex and prone to error or bias.147 The corporate social responsibility bond solves that problem. Indeed, whenever stakeholders value the effects of a corporate decision more than its cost, there should be a possible Coasian bargain between the corporation and the stakeholders that would maximize overall welfare. The bond simply serves as a coordinating device for stakeholders and a way to clearly express preferences.

Possible purchasers include shareholders, employees, and even outsiders, such as nonprofits, family foundations, sovereign wealth funds, mutual funds, and pension funds. Although the latter set of entities is realistically best positioned to pay the large sums of money necessary to fund bonds, they may be concerned about the optics of paying corporations to avoid harm. An environmental non-profit or family foundation might be wary of giving money to ExxonMobil, for example. Perhaps the decision to pay money to ExxonMobil will alienate other donors, or leave less money available for other worthy causes. Although the possibility of alienating donors is a real one, the non-profit could advance a narrative that would be appealing: rarely do donors have such clear opportunities to make a concrete difference in the world as they would by directing corporate decisionmaking for the better.

Not only that, family foundations and nonprofits already partner with corporations in various ways. Often, the goal of the alliance is to raise money for the nonprofit, but not always. For example, nonprofits will sometimes license their names to consumer product companies, giving the underlying product a competitive advantage in the marketplace in exchange for publicity. 148 Critics of this practice contend that this practice represents a sort of quid pro quo: the nonprofit

146 See Hart \& Zingales, supra note 8. Hart \& Zingales recognize that it would be difficult for companies to determine which activities are welfare maximizing for shareholders, and propose shareholder votes as a preference aggregation mechanism. But shareholder voting is a crude method for aggregating preferences along multiple dimensions. The corporate social responsibility bond would allow corporations to more easily determine when certain choices are welfare maximizing — not just for shareholders, but for stakeholders too.

147 See note XX infra.

148 Alan R. Andreasan, Profits for Nonprofits: Find a Corporate Partner, HARV. BuS. REV., Nov.-Dec. 1996 , at 47. 
gives the corporation a reputational boost to offset its wrongdoing elsewhere, and the nonprofit benefits from the increased exposure. 149 By contrast, the use of corporate social responsibility bond is not intended to mask harmful business practices, but reduce them. That fact should ameliorate negative repercussions for the nonprofit that funds a bond.

Other institutional investors, such as mutual funds and pension funds, are unlikely to be a major source of investment for these bonds, but they might contribute occasionally. Indeed, institutional investors that offer pro-social investment vehicles could highlight that they would supplement their voting and engagement efforts with investment in the occasional corporate social responsibility bond. Some prosocial mutual funds could even substitute voting and engagement efforts with donations to corporate social responsibility bonds. This approach is especially appealing for ESG index funds, which promise to track the performance of a baseline index composed of companies that are screened for environmental and social criteria. Major index providers have been launching ESG indices at rapid pace, and investors have been gobbling them up: the largest 120 ESG index funds already have at least $\$ 11$ billion in assets under management, and BlackRock predicts that investment in ESG funds will rise to more than $\$ 400$ billion in the next ten years.150

How are ESG index funds created? First, the index creator adopts a set of standards for inclusion-FTSE Russell, for example, maintains the "FTSE4Good" indices, which include companies that meet certain ESG criteria.151 The indices automatically exclude tobacco companies and manufactures of nuclear weapons, for example.152 An independent committee of experts, NGOs, academics, and investors collaborate on the criteria for inclusion, and periodically review companies' compliance with the standards. 153

Mutual fund sponsors can then license the FTSE4Good indices to be used as the baseline index for their index funds. For example, Vanguard offers a FTSE Social Index fund that seeks to track the performance of the FTSE4Good US Select Index.154 Investors who purchase shares get the benefit of broad diversification in socially responsible companies without having to pay for the underlying research. But they also entrust their governance rights to these funds, which may not always exercise them in a way that investors would want or even expect.

Consider that in the 2019 proxy season, sustainable funds offered by BlackRock, JPMorgan, and Vanguard frequently voted against so-called "green" shareholder proposals.155 This may be

149 Id.

150 Adam Connaker \& Saadia Madsbjerg, The State of Socially Responsible Investing, HARV. BUS. REV. (Jan. 17, 2019), https://hbr.org/2019/01/the-state-of-socially-responsible-investing.

151 FTSE4Good Index Series, FTSE RUSSELL, https://www.ftserussell.com/products/indices/ftse4good (last visited Nov. 11, 2019).

152 But sometimes mistakes are made. See https://www.ft.com/content/fbdb36d0-a293-11e9-974c-ad1c6ab5efd1 (“A $\$ 500 \mathrm{~m}$ exchange-traded fund run by Vanguard that claims to "specifically exclude" fossil fuel stocks invests in a host of companies in the oil and gas industry, amplifying concerns that investors could be misled by socially and environmentally focused products.").

153 Id.

154 https://institutional.vanguard.com/web/cf/product-details/fund/0213

$155 \mathrm{https}: / /$ www.ft.com/content/5d342a5d-443d-3327-9502-2361f37f251c ("For environmental and social proposals that received strong support from investors, six BlackRock sustainability funds voted with a company's management 72 percent of the time.... At Vanguard, two ESG funds, which combined have almost \$7bn of assets, voted with 
because the voting obligations overburden the portfolio managers, as well as the governance groups entrusted with the task of casting these votes. Most mutual fund families centralize their voting within a single stewardship group.156 Sometimes individual funds can depart from the house recommendation, but not always.157 And most often, the index fund portfolio manager will have no interest in participating in governance. Recall that the index fund portfolio manager has delegated the responsibility of gathering firm-specific information to the index creator, and therefore will find it difficult to discharge voting obligations.158 Therefore, ESG index fund holders might find that their votes are being used differently than they would expect or desire.

Vanguard's FTSE4Good fund could fix this problem in a few different ways. It could commit to spending the resources necessary to cast informed votes on ESG issues-likely raising fees by several basis points. Or, it could continue to vote as the institution determines is best for investors and instead devote a small fraction of the fee to corporate social responsibility bonds that are aligned with the fund's philosophy. The latter course of action is equally likely to maximize investor welfare - rather than supporting duplicative governance research, that money would be spent on a bond that would have a chance of changing decision-making for the better.

But in all likelihood, the primary source of corporate social responsibility bonds would not be index funds, but family foundations and other wealthy donors.159 This feature leads to the possibility that these individuals could take advantage of the opportunity to shape corporate decision-making for their own benefit, as will be discussed in Section XX infra.

\section{iv. Enforcement}

Investment is only possible if potential donors have faith that the company will not get to keep the money unless the decision is made. This makes a sophisticated third-party enforcer all the more important. And if the company commits in advance to certain covenants, such as meeting certain pre-defined milestones or being overseen by the third party, that might satisfy donors. Of course, if the company breaches these covenants, they will have to remit the money, providing an incentive to comply. Indeed, the possibility of securing covenants could itself be advantageous for the nonprofit issuer. The nonprofit that is able to secure a right to oversee operations, to take one example, will gain something by having insight into company operations, as well as a voice in the room.

However, the fact that the investors only get their money back if the bond fails could lead to distorted incentives and complicate enforcement. In particular, hedge funds might purchase discounted bonds on a secondary market and then undermine the company's implementation. 160

management on environmental and social issues 93 percent of the time when the proposals won support from at least 40 percent of investors.").

156 Griffith and Lund, Conflicted Mutual Fund Voting, supra note XX.

$157 \mathrm{Id}$.

158 See Adriana Z. Robertson, Passive in Name Only: Delegated Management and “Index” Investing, 795 YALE J. ON REG. 795 (2019).

159

160 The idea of a secondary market for these bonds is somewhat counterintuitive: why would anyone purchase bonds on the secondary market that are unlikely to be worth anything? However, the possibility of a secondary market for "zero-coupon green certificates with zero redemption at maturity" suggests that such a market could exist, especially 
Even if the company claims success, the hedge fund might challenge that decision. The possibility of these transaction costs down the road may limit the usefulness of corporate social responsibility bonds in any situation where compliance with the terms would be difficult to measure.

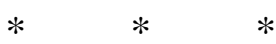

In discussing these details, the limitations of corporate social responsibility bonds are evident. For one, the bond issuer faces an information asymmetry - it might not know enough about the company to dictate the decision, price the bond, and understand how to enforce it. This information asymmetry will be reduced if the company works with the issuer in creating the bond, but that collaboration might also reduce the issuer's leverage in negotiations.

Issuing a bond would also entail high transaction costs, mostly in the form of negotiation and disclosure. It is possible that these transaction costs are too overwhelming for issuers and potential donors to navigate. However, the next section describes recently created financial instruments that aim to link private investors with public and private providers of public goods. Although these instruments entail hefty transaction costs, that has not stopped issuers from creating them and investors from funding them.

If transaction costs and information asymmetries are not insurmountable, why then have corporate social responsibility bonds not been used? One possibility is that innovation in public interested financial products is relatively recent - as the next section reveals, green bonds, carbon offsets, and impact bonds were all created in the past several years. Another likely reason is that corporations are wary to call attention to their bad behavior. For example, when I check out at Whole Foods, I am given the option to donate to a foundation that fights cancer. Why am I not prompted to support a higher wage for the company's own cashiers? Companies are in the business of virtue signaling - not the other way around.161 And this hurdle is likely to most difficult one for issuers of corporate social responsibility bonds to overcome. In fact, there will likely be a firstmover problem: the first corporation to utilize the bond could suffer reputational consequences. Likewise, the first nonprofit to participate might suffer as well, if the public is unhappy about the decision to give a corporation money to offset harm. However, as discussed, a savvy marketing operation could decrease the risk of any reputational blowback - for both the corporation, as well as any nonprofits involved.

But the point remains that the corporate social responsibility bond will not make sense for every company, and for every instance of corporate irresponsibility. For that reason, it should be viewed as a complement to action in other directions-from investors, consumers, employees, politicians, and regulators - rather than a substitute.

C. Analogues

in light of the fact that there is a chance that corporate social responsibility bonds would be repaid. See Matt Levine, Green Bonds Without the Bonds. The benefit of a secondary market is that the bond price would send a signal about the likelihood of the bond's success. The downside is the prospect for manipulation by purchasers. Cf., Gina-Gail

Fletcher, Engineered Credit Default Swaps: Innovative or Manipulative?,

https://papers.ssrn.com/sol3/papers.cfm?abstract_id=3345276.

161 Jillian Jordan \& David Rand, Are You 'Virtue Signaling'?, N.Y. TIMES: OPINION (Mar. 30, 2019),

https://www.nytimes.com/2019/03/30/opinion/sunday/virtue-signaling.html. 
The concept of a corporate social responsibility bond has many analogues in law and finance.162 I discuss three financial analogues in the sections that follow: impact bonds, green bonds, and carbon offsets. I conclude this Section with a discussion of legal analogues.

i. Impact Bonds

"Impact bonds" pool investment from private investors to improve public services.163 Any repayment is contingent upon the achievement of desired outcomes - if the objectives are not met, investors get nothing; if the project succeeds, usually far down the road, the investors make their money back.164 In other words, the public entity only needs to repay investors if the project provides its intended benefit. 165

These instruments are relatively new. Indeed, Goldman Sachs' Urban Investment Group launched the first social impact bond in the United States in 2012-a \$9.6 million loan for therapy services for juveniles incarcerated at Rikers Island.166 The transaction was structured as follows: Goldman made funds available to the nonprofit MRDC, and the nonprofit used the funds to hire the Osborne Association, which provides therapy services to incarcerated youth.167 MRDC was charged with overseeing the day-to-day implementation of the project. In addition, the Vera Institute of Justice, another nonprofit center for justice policy, was tasked with evaluating whether the program reduced the recidivism among Rikers inmates.168 The City of New York agreed to provide success payments to MDRC based on the projected savings from the reduced recidivism rate after five years, informed by the Vera Institute's evaluation. To illustrate: a $20 \%$ reduction in recidivism would result in an estimated savings of \$20.5 million for the city.169 If Vera and MRDC determined that the program had led to a $20 \%$ reduction in recidivism, the city would pay MDCR about half of that sum. Bloomberg Philanthropies also made a guarantee of \$7.2 million, reducing Goldman's risk that it would not be repaid.

As this example shows, impact bonds encourage ventures that improve the efficiency of public services and are expected to generate financial benefits at some future date. Public sector organizations often lack funding and political fortitude to take on such risks, even if they will pay off down the line; impact bonds therefore unite the public sector with private suppliers of capital,

162 For a discussion of an analogous concept proposed by Michael Abramowicz and Ian Ayers, see Compensating Commitments: the Law and Economics of Commitment Bonds that Compensate for the Possibility of Forfeiture, https://papers.ssrn.com/sol3/papers.cfm?abstract_id=1612396.

163 See Rebecca Leventhal, Effecting Progress: Using Social Impact Bonds to Finance Social Services, 9 N.Y.U. J.L. \& Bus. 511 (2013).

164 See id. Note that this is the opposite of how I propose the corporate social impact bond would operate. Although making repayment contingent on achievement of the outcome provides an incentive for it to be achieved, it also creates the prospect of a lose-lose situation: one in which investors get nothing, and neither does the public.

165 For a discussion of the tax consequences of impact bonds, see Orly Mazur, Taxing Social Impact Bonds, 20 Florida Tax Review 432 (2017).

166 John Olson \& Andrea Phillips, Goldman Sachs, Rikers Island: The First Social Impact Bond in the United States, 9 Community DeV. INV. REv. 97 (2013). Other social impact bonds solicit investment from multiple investors. See Leventhal, supra note 163 , at 458.

167 Id.

168 Id.

169 Id. 
and if the venture is successful, allow those suppliers of capital to share in the proceeds. Of course, a for-profit company is not limited in the same way: Management is free to pursue any strategy designed to maximize profits, and will likely be able to secure funding to support them. The key difference, therefore, between an impact bond and the instrument I envision is that the latter will be used to push companies (and not public entities) to make money-losing choices, rather than profitable ones. Although the company will receive money to offset the costs, the main point of the bond is not to raise money, but to encourage the company to make the public-interested choice.

The fact that the choice is money losing, however, means that the social responsibility bond donor will not be paid if the bond is successful. Although this structure results in a win-win of sorts - the donor either gets the money back or has the satisfaction of knowing that the donation made a real impact - there is also the prospect of distorted incentives discussed in the previous section.

\section{ii. Green Bonds}

Another analogue is a so-called "green bond." Green bonds earmark funds for corporate projects that benefit the environment.170 These bonds were invented by the World Bank in 2007; investment in green bonds has escalated since then, breaking a record with $\$ 107$ billion issued in the first half of 2019.171

Here's how green bonds work: An issuer solicits funds for a "green" project, defined as a project with a positive environmental benefit. 172 Importantly, the bond price is generally the same as an ordinary bond from that issuer, and recourse is also the same.173 The main difference is that the funds are earmarked for qualifying green projects. This could include starting a new green project, as well as refinancing existing projects to make them green. Thus far, development banks have been the largest issuers, 174 but major companies, including Apple and SolarCity have issued

170 Financing the Transition to a Green Economy: Their Word Is Their (Green) Bond?, CLIMATEBRIEF (CDC Climat Research, Caisse des Dépôts, Paris, Fr.) May 2012, https://www.i4ce.org/wp-core/wp-

content/uploads/2016/03/12-05-Climate-Brief-14-Financing-the-transition-to-a-green-economy-their-word-is-theirgreen-bond.pdf.

171 Nina Chestney, Green Bond Issuance Surpasses $\$ 100$ Billion So Far This Year; Data, REUTERS: Sustainable Bus. (June 25, 2019, 8:03 PM), https://www.reuters.com/article/us-bonds-environment/green-bond-issuancesurpasses-100-billion-so-far-this-year-data-idUSKCN1TQ11V. See also Olivier David Zerbib, The Effect of Proenvironmental Preferences on Bond Prices: Evidence from Green Bonds, J. BANKING \& FIN., Jan. 2019, at 39 (showing a steady increase in green bond issuance on page 4).

172 For more information about the requirements for issuing a green bond, see The Green Bond Principles, INT'L CAPitAl MKt. Ass'N, THE GREEN BOND PRINCIPLES, 2016 (2016), http://www.icmagroup.org/assets/documents/Regulatory/Green-Bonds/GBP-2016-Final-16-June-2016.pdf. 173 OECD, MOBILISING BOND MARKETS FOR A LOW-CARBON TRANSITION (2017) (stating that the financial characteristics of green bonds and conventional bonds produced by the same issuer are identical at the issue date); see also IGOR SHISHLOV ET AL., INST. FOR CLIMATE ECON., BEYOND TRANSPARENCY (2016)

(arguing that there is "no clear evidence" that green bonds reduce the cost of capital for their issuers).

174 Zerbib, supra note XX. 
green bonds175; government bodies - including the state of Massachusetts - have also issued green municipal bonds. 176

The main difference between a green bond and corporate social responsibility bond is that the latter is designed to push companies to make undesirable choices, at least, from the perspective of wealth maximization. By contrast, a green bond simply allows companies to secure funding for profit-maximizing green projects - projects that would be worth the cost of the debt.177 The fact that lenders charge the same rate for green bonds and "brown" bonds indicates that the lenders are not placing much of a constraint on decisionmaking, as borrowers are not in the habit of taking on onerous constraints for free.

Take Apple's second green bond offering as further support for this point. Shortly after the Trump administration announced that it would withdraw from the Paris Climate Agreement, Apple issued a green bond of $\$ 1$ billion, following a larger green bond issuance a few years before.178 It announced that these funds would support projects to reduce emissions in Apple's corporate facilities, stores, and supply chain.179 The company explained that if implemented, these projects would save the company money over time. 180 Not only that, Apple had already announced that all of the company's facilities were powered by renewable energy; these funds were being used to "maintain that achievement." 181 In sum, the green bond funding went toward supporting projects that had already promised to take on, or that it had plenty of incentives to do already. There is no evidence that the presence of green bond funding actually caused Apple to make profit-sacrificing decisions. 182

175 Apple, AnNual Green Bond IMPACt RePort (2018); Beate Sonerud, Climate Bonds Initiative, SolarCity Issues US\$200m of Retail Bonds, Maturity Ranging from 1-7 Years, Coupon 2-4\%. What a Pioneering Company! First Public Solar Bond Offering in the US, After Also Doing the First Solar Securitisation in 2013, CLIMATE BONDS INITAITIVE (Oct. 16, 2014), https:/www.climatebonds.net/2014/10/solarcity-issues-us200m-retail-bondsmaturity-ranging-1-7-years-coupon-2-4-what-pioneering. 176 Mass. Clean Water Tr., Annual Green Bonds Report (2019). Denmark has issued sovereign green bonds with an interesting and unique feature: the promise to spend money on green projects is separable from the actual bond and able to be traded in the secondary market. That is so despite the fact that the green certificate is a zerocoupon bond with zero redemption at maturity. See Matt Levine, Green Bonds Without the Bonds, https://www.bloomberg.com/opinion/articles/2019-12-06/green-bonds-without-the-bonds.

177 Indeed, some green bonds might not even support green projects. See https:/www.bloomberg.com/news/articles/2019-11-07/green-bonds-get-rubber-stamped-as-investors-question-thelabel

178 It is somewhat puzzling that Apple, a company with $\$ 257$ billion in cash on hand, would borrow money. Lauren Feiner, Apple Now Has \$345 Billion Cash On Hand, up 3\% from Previous Quarter, CNBC: TECH (Jan. 29, 2019, 4:38 PM), https://www.cnbc.com/2019/01/29/apple-now-has-tk-cash-on-hand.html (last updated Jan. 29, 2019, 6:38 PM); https://www.ft.com/content/db5b911e-508a-11e7-bfb8-997009366969. The answer is likely that Apple wished to avoid tapping into offshore cash reserves. https://www.ft.com/content/af9a76a4-d4ca-11e5-8887-98e7feb46f27. In addition before 2017, green bond issuers were eligible for tax advantages. See https://www.irs.gov/pub/irsdrop/n-18-15.pdf.

179 Id.

180 Id.

181 APPLE, supra note 175.

182 See also Caroline Flammer, https://www.bu.edu/gdp/files/2018/11/GEGI-GDP.WP_.Corporate-Green-Bonds.pdf (showing that green bond issuance is correlated with improved financial performance, as measured by stock price reaction). 
Therefore, the main difference between a green bond and a corporate social responsibility bond is that the latter encourages companies to make profit-sacrificing choices. A corporate social responsibility bond, for example, might be used to push Apple to better accommodate consumers who want to upgrade their electronics, rather than replace them, which would reduce carbon emissions created during the manufacturing process, as well as landfill waste. 183 This would likely have a larger environmental impact than building a LEED certified Apple store in Japan, but of course, would sacrifice profits, and therefore, no amount of green bond funding for the same interest rate would encourage the company to do it.

\section{iii. Carbon Offsets}

Individuals who are concerned about the impact of activities that generate greenhouse gas emissions can purchase carbon offsets, which fund emission reduction projects elsewhere.184 For example, if I am forced to take a cross-country flight for business travel, I cannot easily avoid the expansion of my carbon footprint. A non-profit like TerraPass offers me the opportunity to purchase an offset for every one metric ton of carbon dioxide emissions that my flight created. 185 Indeed, some companies give consumers the option to purchase offsets in order to (supposedly) directly offset the emissions created by the consumption of their products. For example, most airlines provide an opportunity for passengers to offset the emissions produced by their trip.186 Oil and gas companies often do, too: Shell gives customers in the Netherlands the option to pay .01 euro per liter of fuel which the company uses to buy carbon credits that offset the carbon emissions associated with their purchase. 187 These offset funds go toward funding projects that reduce carbon dioxide emissions, including planting trees, initiating gas capture projects at landfills, and funding wind power.188 And these campaigns have been quite successful in attracting participation: Nearly $\$ 4.5$ billion had been spent on offsets from 2005 to 2015.189

Like a carbon offset, the corporate social responsibility bond is a voluntary market transaction by individuals who are concerned about externalities created by the companies with which they interact. I might enjoy shopping for cheap products at Wal-Mart, but remain concerned that my consumer surplus is taken from employees who do not earn living wages. As with a carbon offset, I can compensate for some of this harm by investing in a corporate social responsibility bond directed at improving working conditions and wages for Wal-Mart employees.

But corporate social responsibility bonds offer additional benefits. A carbon offset offers a consumer a chance to pay for the harm they generate, instead of making changes in their lifestyle that would reduce emissions. The purchaser of the corporate social responsibility bond, however,

183 David L. Veksler, Apple Is Not as Green As It Seems, FEE (Oct. 15, 2017), https://fee.org/articles/applesenvironmental-claims-are-misleading/.

184 NADAA TAIYAB, EXPlORING THE MARKET FOR VOLUnTARY CARBON OFFSETS (2006).

185 Carbon Offsets Explained, TERRAPASS, https://www.terrapass.com/climate-change/climate-changecarbon-offsetsexplained (last visited Nov. 12, 2019).

186 Katie Genter, Everything You Need To Know About Carbon Offsetting for Your Flights, POINTs GuY (Oct. 7 , 2019), https://thepointsguy.com/guide/a-guide-to-airline-carbon-offset-programs/.

187 Akshat Rathi, Shell Will Spend \$300 Million To Offset Carbon Emissions. Here’s the Catch, QUARTZ (Apr. 10, 2019), https://qz.com/1590325/whats-wrong-with-shells-plan-to-offset-your-carbon-emissions/.

$188 \mathrm{Id}$.

189 Kelly Hamrick, Forest Trends, Ahead of The Curve (Molly Peters-Stanley \& Gloria Conzalez eds., 2015). 
has no other option to generate the prosocial good - they are trying to encourage a choice that wouldn't otherwise be made.

However, criticism of offset markets has analogues here too. For example, some environmentalists believe that the ability to offset carbon emissions will discourage people from taking steps to reduce their carbon footprint. 190 (As support for their point of view, consider why airlines and oil and gas companies offer offset opportunities to their customers ). Likewise, as discussed, it is possible that the prospect of receiving money as compensation for harmful activities will weaken any impetus for companies to stop them; indeed, it could even encourage companies to increase harmful activity in order to solicit payments from bond issuers.191 Perhaps, for example, the polluting coal company would decide to emit even more pollution in an effort to try to attract bond proceeds.

The possibility for moral hazard should weigh on the mind of anyone considering whether to use corporate social responsibility bonds. But in many circumstances, corporate reputational considerations should limit moral hazard. Unlike individual polluters, corporations who do harm are subject to constant scrutiny-from the news media, consumers, employees, regulators, and shareholders.192 This scrutiny should serve as a constraint on corporations who might otherwise feel encouraged to engage in worse behavior in order to secure funding from corporate social responsibility donors. Relatedly, if the receipt of funds is not guaranteed, risking bad behavior is especially unlikely to pay off. Unless this tool becomes ubiquitous-which is unlikelycorporations are unlikely to hold back social responsibility efforts in order to attract bond proceeds.

Nonetheless, the prospect of moral hazard should influence corporate social responsibility bond issuers and their processes, especially if the bonds become common. For example, an issuer

190 See, e.g., Ascelin Gordon et al., Forum, Perverse Incentives Risk Undermining Biodiversity Offset Policies, 52 J. APPLIED ECOLOGY 532 (2015).

191 A related critique is that monetary incentives can "crowd out" altruistic incentives. See Richard Titmuss, The Gift Relationship (1970) (positing that monetary compensation for donated blood would reduce the supply of donors);

Carl Mellström \& Magnus Johannesson, Crowding Out in Blood Donations: Was Titmuss Right?, 6 J. Eur. Econ.

Ass'n 845 (2008) (confirming these results). As an example, a study of Israeli daycare attendees found that lateness increased when parents were not prohibited from coming late, but instead were asked to pay a fine. See Uri Gneezy \& Aldo Rustichini, A Fine Is a Price, 29 J. Legal STUD. 1 (2000).

Other studies have likewise demonstrated that economic incentives can backfire or be counterproductive. See, e.g., Bruno S. Frey \& Felix Oberholzer-Gee, The Cost of Price Incentives: An Empirical Analysis of Motivation Crowding-Out, 87 AM. ECON. REV. 746 (1997) (providing survey data showing that individuals were less likely to accept locating a nuclear waste facility in their neighborhood if they were offered monetary compensation); see also Yochai Benkler, The Unselfish Gene, HARV. BUS. REV., https://hbr.org/2011/07/the-unselfish-gene (last visited Nov. 12, 2019).

("Whenever you design a policy that relies on monetary rewards, you have to assume that it will have side effects on the psychological, social, and moral dimensions of human motivation. A change that would lead to more behavior of the kind you are rewarding, or less of the kind you are punishing, may cause the exact opposite behavior because the effects on the material self-interest vector will be more than canceled out by the effects on the intrinsic motivation vectors.").

However, crowding-out is less likely to occur when the target of the incentive payment is a corporation, rather than an individual. Corporations do not have altruistic feelings, nor do they have intrinsic motivation. And while corporations are populated by employees, but those employees do not directly benefit from the reward in questionthe entity does.

192 John L. Campbell, Why Would Corporations Behave in Socially Responsible Ways? An Institutional Theory of Corporate Social Responsibility, 32 Acad. Mgmt. Rev. 946 (2007). 
of bonds might refuse to work with a company that seeks out a bond. Or, an issuer could adopt a policy of only working with companies that have made genuine efforts at improving its ESG activities over time.

iv. Legal Analogues

The idea of paying corporations to engage in beneficial activity is unpalatable in many ways. Indeed, some may view paying people to stop causing harm as morally problematic.193 But in many instances, our government does just this: it provides incentives for private parties to take action that benefits the public good. For example, the United States government provides billions of dollars in "climate aid" each year; these funds are used by development banks and foreign countries to help those developing countries achieve environmental goals. 194 The idea is that this money will encourage developing countries to make green choices-reducing ozone emissions, carbon emissions, cleaning chemical waste, stopping deforestation, 195 etc.- that would not otherwise be made without financial support. Of course, there is also a justice-based argument supporting this aid: developing countries might reasonably ask why they are the ones that should make developmental sacrifices to mitigate problems that developed countries created and benefitted from.

But in other contexts, the government offers subsidies in the form of tax deductions for prosocial behavior simply to encourage it. The deduction for charitable donations is an obvious example. Individuals who donate to eligible non-profits are able to offset some of that cost by paying lower taxes.196 Indeed, charitable deductions are also available for other prosocial activities - such as giving up an easement to develop your property in favor of conservation. 197 In these cases, we do not think that it is morally problematic to compensate individuals who voluntarily act to promote the public interest; indeed, we are grateful that the subsidy exists, or else such activity might not happen.198

193 See also Daniel Hemel \& Dorothy S. Lund, Sexual Harassment and Corporate Law, 118 COLUM. L. REV. 1583 (2018) (discussion on discursive harm).

194 Joe Thwaites, US Climate Finance Improves with 2019 Budget, but There's Still a Long Way To Go, WORLD RESOURCES INST. (Feb. 20, 2019), https://www.wri.org/blog/2019/02/us-climate-finance-improves-2019-budgettheres-still-long-way-go. The United States supports two global environmental funds: the Montreal Protocol Multilateral Fund, which helps developing countries eliminate ozone-depleting substance, as well as the Global Environment Facility, which collects funds to help support environmental initiatives in the developing world. It also supports climate finance through the State Department and USAID. Id.

195 Relatedly, "Payment for Ecosystem Services" programs link rich funders with people in poor countries that would be tempted to chop down trees for income. Those people are instead paid to protect their forests. These programs have been used in Costa Rica, Mexico, China, and Bolivia, and have been found to be very successful at averting climate destruction. See Ed Young, The Success of Paying People to Not Cut Down Trees, the Atlantic (July 20, 2017).

196 See Ellen P. Aprill, Churches, Politics, and the Charitable Contribution Deduction, 42 B.C. L. REV. 843 (2001). Indeed, the "charitable deduction makes the government a partner in every gift-giving venture" and can be seen as a form of voting, in which individuals direct government resources to their preferred uses. Saul Levmore, Taxes As Ballots, U. Chi. L. Rev. (1996). Corporations are also entitled to take a tax deduction for charitable donations. 197 Peter J. Reilly, Crackdown on Conservations Easement Syndications, FORBES, https://www.forbes.com/sites/peterjreilly/2018/12/20/crackdown-on-conservation-easementsyndications/\#3645120016fa (last visited Nov. 12, 2019).

198 Eminent domain for economic development provides another example of paying individuals or entities to take action that is in the public good: it is legally permissible for the government to force individuals to part with their 
However, it is certainly more controversial when the government subsidizes corporate behavior with the goal of benefitting the broader community. Recall Amazon's search for a secondary corporate headquarters which led to fierce competition among states that promised tax incentives and other benefits. The eventual winner-New York-ultimately promised approximately $\$ 3.4$ billion in tax incentives to attract the company's corporate headquarters.199 The reason, of course, is that luring the corporate giant to New York would have many offsetting benefits for the state-thousands of new jobs (supposedly),200 increased revenue from sales and income tax, redevelopment plans, etc. - that likely exceeded the costs. But that did not stop fierce protests by residents and public officials. "Amazon is a billion-dollar company," Representative Alexandria Ocasio-Cortez tweeted.201 "The idea that it will receive hundreds of millions of dollars in tax breaks at a time when our subway is crumbling and our communities need MORE investment, not less, is extremely concerning to residents here."202 These protests eventually led to Amazon to abandon its plan to build a second corporate headquarters in New York.203

The corporate social responsibility bond concept could be plagued by a similar conceptual problem: even if the bond would maximize social welfare, the idea of paying a corporation to move in a positive direction might be unpalatable to many. However, the benefit of the bond concept is that it links private donors with private entities. If individuals want to subsidize corporate decisionmaking in order to generate large social benefits, why shouldn't they? Although taxpayers will support the decision to the extent that the donation is tax deductible, this limited subsidy provides less of a moral problem than the large direct subsidies that citizens ultimately pay when local and state governments attempt to incentivize corporate behavior that benefits the locality.

\section{Unintended Consequences}

I have already considered whether corporate social responsibility bonds could lead to moral hazard-encouraging corporations to act worse than they would otherwise in order to seek payouts. Could the issuance of a corporate social responsibility bond (or the possibility of the issuance) lead to other unintended consequences?

For example, the issuance of a corporate social responsibility bond could redirect nonprofit attention away from worthy causes. Nonprofits have limited resources available to achieve a social impact. Perhaps the issuance of a corporate social responsibility bond could eat up valuable time

land in service of an economic project that will create new jobs, increase tax and other city revenues, or revitalize a depressed urban area. See Kelo v. City of New London, 545 U.S. 469 (2005).

199 Jack Stewart \& Marielle Segarra, After Political Resistance and Protests, Amazon HQ2 in New York Is No More, MARKETPLACE (Feb. 14, 2019), https://www.marketplace.org/2019/02/14/after-political-resistance-and-protestsamazon-h2q-new-york-no-more/.

200But see Austin Carr, Inside Wisconsin's Disastrous \$4.5 Billion Deal with Foxconn, BLOOMBERG BUSINESSWEEK (Feb. 6, 2019, 7:00 PM), https:/www.bloomberg.com/news/features/2019-02-06/inside-wisconsin-s-disastrous-4-5billion-deal-with-foxconn.

201 Alexandria Ocasio-Cortez (@AOC), TwITTER (Nov. 12, 2018),

https://twitter.com/aoc/status/1062204614496403457?lang=en.

$202 \mathrm{Id}$.

203 Day One Staff, Update on Plans for New York City Headquarters, about amazon (Feb. 14, 2019),

https://blog.aboutamazon.com/company-news/update-on-plans-for-new-york-city-headquarters. 
and resources that would be better spent elsewhere - such as by lobbying for externality regulation, or by organizing a consumer boycott. This reality may further decrease the likelihood that corporate social responsibility bonds will be issued-given the limited time and resources of nonprofits, these bonds will only be palatable when they offer a greater social return on investment than other prosocial projects.

But there is reason to think that on occasion, these bonds will be a useful complement to nonprofit efforts elsewhere. Indeed, corporate social responsibility bonds could aid nonprofits and regulators by forcing disclosure about harmful corporate practices. As discussed, a company that wants to issue a bond or work with a nonprofit issuer will have to disclose information about its business practices. It may even need to allow the third-party to monitor its operations. This disclosure could help nonprofits understand harmful corporate behavior; it could also aid regulators seeking to regulate the industry in the future.204 And as discussed, the corporate social responsibility bond could ease the prospect of regulation in another way: it could convert the targeted company into a proponent of regulation that would bind rivals. 205

But the issuance of a corporate social responsibility bond could have a different harmful consequence: it could direct donor and investor attention away from other worthy causes. An individual will likely only donate a certain amount of money to charity each year. Likewise, an investor may be less willing to invest in benefit corporations or SRI mutual funds if they have donated to corporate social responsibility bonds. But this consequence has some advantages. As discussed, SRI mutual funds provide an opportunity for investors to invest in companies that align with their values, without offering any real opportunity to alter corporate decisionmaking. 206 These funds rarely advertise that fact, and often obscure it.207 Therefore, the issuance of a corporate social responsibility bond could draw attention to the fact that sacrificing returns is necessary to alter corporate decisionmaking, and help alleviate investor misunderstanding about what their investment in SRI mutual funds will really accomplish. Ultimately, my hope is that corporate social responsibility bonds would be used only where they would have a substantial and tangible impact - therefore supplementing action in other areas, rather than chipping away at it.

A larger concern is that the prospect of a corporate social responsibility bond will decrease the incidence of voluntary corporate social responsibility. For example, what B Corp will survive when it has to compete with a company that is being paid to make the same choices? I suspect that many B Corps are not sacrificing profits for the reasons discussed in the first part of this paper: genuine profit-sacrifices are unlikely to exist (and if they do, they are unlikely to do so for long). In other words, it is likely that B Corps signal their alignment with social goals for profitmaximizing reasons.208 But the point remains that if all companies are induced to act like B Corps,

204 Note, however, that a company that fears that greater disclosure will lead to regulation and other harmful consequences, they will be less likely to accept the money. This reality constrains the risk of moral hazard.

205 However, government bodies could see the efforts of private sector financing as evidence that the area is a lower priority for legislative action. For that reason, perhaps the use of social responsibility bonds should be limited to domains where it appears unlikely that regulation would be forthcoming because of industry capture or other reasons. 206 Brest et al., supra note 31.

$207 \mathrm{Id}$.

208 Suntae Kim et al., Why Companies Are Becoming B Corporations, Harv. Bus. Rev. (June 17, 2016), https://hbr.org/2016/06/why-companies-are-becoming-b-corporations ("Having a clear identity can help firms communicate their values to customers, which is particularly beneficial when they are claiming an identity different 
B Corps may have less of a competitive advantage. But like the concern about moral hazard, this problem would only arise if corporate social responsibility bonds become ubiquitous. It is unlikely that corporate social responsibility bonds will be used often enough to threaten B Corps across all industries; and were that to occur, the social welfare benefits would likely exceed this cost.

However, the issuance of corporate social responsibility bonds could result in perverse distributive consequences. For example, a wealthy community could organize a corporate social responsibility bond in the guise of offsetting environmental impact, but with the effect of moving a planned factory into a poorer, less-populated area. But notice that in the absence of a corporate social responsibility bond, the wealthy community could still obtain this result - through lobbying, or behind-the-scenes conversations with legislators and the company. At the very least, the corporate social responsibility bond would increase the transparency of such actions-perhaps making them less likely to happen this way.

But this example reveals a deeper problem: an individual's willingness to pay might not lead us to the social welfare-maximizing choice. For example, a wealthy individual who dislikes millennials could design a bond to induce Wal-Mart to only hire people born before 1979 — which is unlikely to further the public interest. But, there are a few reasons to think that bonds will not be used for this purpose. For one, Wal-Mart would likely experience public backlash if it accepted proceeds to support an action that most people oppose. That backlash could make the bond prohibitively expensive for the ageist donor. And the bond could also increase the likelihood of regulation, especially if the course of action was widely unpopular-making the tool unappealing for both the donor and the company. Indeed, the prospect of backlash and regulatory scrutiny would likely lead to company to refuse to participate.

Ultimately, however, there is no guarantee that bonds that are privately welfare maximizing will be aligned with the public interest. (The same is, of course, also true of a stakeholder model, which simply asks corporations to maximize the welfare of a larger group). But for the reasons discussed above, bonds that do not further the public interest are unlikely to succeed.

Finally, the existence of a corporate social responsibility bond might do damage to the corporate stakeholder movement more broadly by entrenching a shareholder primacy point of view. Advocates of the stakeholder view believe that the goal is to move away from a conception of the corporation that prioritizes investor wealth over all other interests.209 By working within the wealth-maximization framework, the corporate social responsibility bond could undercut efforts to shift to a different paradigm. But once again, the use of a corporate social responsibility bond is not intended to supplant action in other domains. It is possible for proponents of a stakeholder or team-production model of the corporation to continue to work to implement that perspective, even

from the industry norm.”); James Surowiecki, Companies with Benefits, NEW YORKER: FIN. PAGE (July 28, 2014), https://www.newyorker.com/magazine/2014/08/04/companies-benefits ("[A]t the operational level, having a social mission can offer distinct advantages. It's an important way for a company to attract and retain talented employees. Survey data show that workers - especially young ones-want to work for socially conscious companies, and will take less compensation in exchange for a greater sense of purpose... Having a social mission can also be an important selling point with consumers, as the success of the fair-trade movement makes clear.").

209 See COLIN MAYER, ProsPerity (2018); STOUT, supra note 8;

Stout \& Blair, supra note 8; Brett McDonnell, The Corrosion Critique (Sept. 18, 2019) (unpublished manuscript), https://papers.ssrn.com/sol3/papers.cfm?abstract_id=3450747. 
alongside efforts intended to improve corporate decisionmaking in the near-term. As discussed, a paradigm shift would require major changes; insulation from market forces, or awarding enforceable rights to groups other than shareholders, to name just two options.210 In the meantime, this article offers a possibility that could begin to work right away. And because the circumstances in which it may work are ultimately narrow, the opportunity to issue a bond is unlikely to convince many people that further action-from academics, regulators, consumers, shareholders, and employees - is unnecessary.

\section{E. Alternatives}

The advantage of a corporate social responsibility bond is that it would encourage corporations to make public interested choices that they would not otherwise make. But this is not the only option that would encourage prosocial corporate decisionmaking. This section explores other possibilities.

Instead of issuing a corporate social responsibility bond proactively, major lenders could tailor the cost of the debt to achieving certain E\&S milestones.211 For private equity funds that are concerned about minimizing the amount of free cash flow spent servicing debt, the possibility of a reduction in borrowing costs could be a powerful motivator. Consider CEC Entertainmentbetter known as the parent company of Chuck E Cheese.212 If the CEC's creditor banks were to drop the current interest rate on the total debt by $2.5 \%$, that would result in a pool of cash capable of raising every employee's wage by $10 \%$. Indeed, a lender could even announce that the interest rate associated with any prospective loan will decrease if the company meets certain pre-defined E\&S milestones.

But lenders of capital are not likely to give money away. Instead, perhaps lenders could offer a low rate of interest and specify that certain anti-social actions would trigger the imposition of a higher rate of penalty interest. In this way, lenders could encourage a company to maintain socially responsible practices. And companies might be inclined to agree if their commitment allows them to secure a favorable interest rate initially.

Another option would be to use social responsibility mutual funds to provide pools of capital for profit-sacrificing decisions.213 As discussed, SRI mutual funds essentially hold shares of companies that meet certain social or environmental criteria and have attracted a record-breaking amount of money in the past few years.214 That is so despite the fact that these funds generally have higher expense ratios; it seems that investors are willing to pay slightly more for funds that meet their standards for good corporate citizenship.215 The problem is that investing in SRI mutual funds doesn't itself encourage corporate social responsibility: even if a large number of prosocial

210 See Lund and Pollman, The Corporate Governance Machine (unpublished manuscript).

211 See Brest et al., supra note 31.

212 Siddarth Cavale et al., Apollo Global To Swallow Chuck E Cheese, REUTERS (Jan. 16, 2014, 5:45 PM),

https://www.reuters.com/article/us-cecentertainment-apollo/apollo-global-to-swallow-chuck-e-cheese-

idUSBREA0F0CL20140116.

213 A corporate social responsibility bond could also be used to support the lender's decision to lower interest rates.

214 See supra note XX.

215 David Kathman, Are Sustainable Funds More Expensive?, MORNINGSTAR (Mar. 16, 2017),

https://www.morningstar.com/articles/798280/are-sustainable-funds-more-expensive. 
investors refuse to buy sin stocks, there are other investors that will be happy to buy the nowdiscounted stock.216 Perhaps these investors hope that these funds will use their shareholder rights to push for social change. But as mentioned, often these prosocial funds fail to use their voting power to support environmental and social proposals.217

Is there a better way to harness investor appetite for corporate social responsibility and still assure them some return? One way to do this would be to model SRI mutual funds after green bonds, but with more stringent criteria for corporations seeking to borrow the money. Like a green bond, investors would pool their money and make it available for corporations that meet the funds' exacting guidelines. But instead of charging the same rate of interest, the investors would agree to accept a lower rate; in exchange, the company would commit to ensuring that the funds would only be used for projects that meet the fund's exacting criteria.218 This tool would therefore encourage companies that are looking for cheap cash to alter their business practices.

But some projects are not undertaken not because they are profit sacrificing, but because they are NPV uncertain. Although a bond could be used to support these choices, another possibility would be to use an instrument that allows for donor repayment if the corporate decision ends up making the company money. The pseudo-earn out mechanism discussed above is a possible tool. Another option would be for ESG investors to use warrants to help the company hedge against uncertainty. That is, an investor would give the company money in exchange for the option to purchase stock at the current price at some time in the future, after the prosocial decision is made.219 If the investor is right about the project and its potential, they will profit from the option. And more importantly, the company will receive downside protection for the risk associated with undertaking the project.

\section{Broader Implications}

The previous sections explored how corporate outsiders could encourage public interested corporate decisionmaking by expanding the set of profitable decisions. A key implication of this analysis is that the individuals and entities with the strongest interest in seeing corporations pursue corporate social responsibility goals are not necessarily the company's shareholders. From that observation comes several additional implications with broad consequences for corporate law and corporate governance. The first and most obvious implication is that our system of corporate law, as it is currently constituted, is unlikely to lead to socially optimal levels of corporate social responsibility.220 Corporate stakeholders and even outsiders may place a high value on corporate

216 Brest et al., supra note 31 (describing the problems with divestment campaigns). Even the divestment campaigns by the influential Norwegian sovereign wealth fund didn't make much of a difference in corporate strategy at the targeted companies. James Mackintosh, Even \$1 Trillion Can't Make World Better Place, Wall Street J. (June 30, 2019, 12:17 PM), https://www.wsj.com/articles/even-1-trillion-cant-make-world-better-place-11561906980. Other problems with ESG funds, and in particular, ESG index funds, exist, including a lack of transparency about the composition of the baseline indices. Dana Brakman Reiser \& Anne Tucker, Buyer Beware: The Paradox of ESG \& Passive ESG Funds (Aug. 23, 2019) (unpublished manuscript), https://papers.ssrn.com/sol3/papers.cfm?abstract_id=3440768.

217 See supra note XX.

218 Favorable tax treatment could offset investor losses.

219 Note complication that issuing options to public investors would likely require a public offering.

220 See Gordon, supra note 65. 
social responsibility and nonetheless lack meaningful mechanisms to influence corporate behavior, especially when their preferred course of action conflicts with wealth maximization. Therefore, mechanisms that elevate the voices of corporate outsiders in decisionmaking is likely to improve overall welfare. The bond concept explored in this article is just one mechanism aimed at doing this - other methods, such as increasing worker voice - could help move the balance of power in a better direction. 221

A second and related implication is that we should recognize the limits of shareholder activism to achieve optimal levels of corporate social responsibility. Yes, shareholders may have prosocial goals, and some shareholders may even wish to prioritize those prosocial goals over wealth maximization. But the fact remains that most shareholders are only interested in corporate social responsibility that is also wealth maximizing.222 Moreover, the most influential and powerful shareholders that could credibly threaten management with a proxy fight or other interventionthe squeaky wheel, so to speak - are very much focused on wealth maximization.223

What about large, broadly diversified institutional shareholders? Many scholars have focused on these "universal owners" as a possible solution to major social problems ranging from climate change 224 to systemic risk.225 The claim is that universal owners should have an incentive to reduce the risk of problems that would threaten their portfolio-which includes the entire market. In theory, therefore, a universal owner should push a polluting company to raise emissions standards, even if doing so would sacrifice profits, if reduced emissions would safeguard the long-term health of the portfolio as a whole.226

I am skeptical that universal owner engagement is the solution, however. Even if universal owners did take a portfolio-level view of their responsibilities - and the largest universal owners generally deny that this is the case227-how would these investors successfully implement such a

221 S. 3348, 115th Congress (2018); Strine, supra note 19. Another possible solution would utilize voting markets to transfer votes for CSR issues to the individuals who value them most-who will not necessarily be the shareholders. 222 See CII response to BRT letter, supra note XX; see also VANGUARD, INVESTMENT AND STEWARDSHIP (2019) ("We believe that good governance practices ... are the foundation on which a company's board of directors can build enduring shareholder value.”); Protecting and Enhancing Our Clients' Assets for the Long Term.,

BLACKROCK, https://www.blackrock.com/corporate/about-us/investment-stewardship\#our-responsibility (last visited Nov. 13, 2019).

("Our engagement priorities promote sound corporate governance and business practices that are consistent with sustainable long-term financial return.”); https://www.ssga.com/about-us/asset-stewardship.html

("Our stewardship program utilizes a risk-based approach to identify material ESG thematic topics deemed to have the most material impacts on the long-term value of our portfolio companies.").

223 See Marcel Kahan \& Edward B. Rock, Hedge Funds in Corporate Governance \& Corporate Control, 155 U. Pa. L. Rev. 1021 (2007).

224 Barzuza et al., supra note 54; Condon supra note 36; Strine, supra note XX.

225 Yesha Yadav, Too-Big-To-Fail Shareholders, 103 Minn. L. Rev. 587 (2018); Gordon, supra note 65.

226 Condon, supra note 36.

$227 \mathrm{Cf}$. https://www.blackrock.com/corporate/literature/publication/ftc-hearing-8-competition-consumer-protection21st-century-011419.pdf; https://www.blackrock.com/corporate/literature/whitepaper/viewpoint-index-investingand-common-ownership-theories-eng-march.pdf ("Asset managers often offer a variety of investment products, using both index and active strategies, and, as discussed earlier in this paper, each portfolio is managed according to a separate investment mandate. As a result, ascribing a single view on a particular security to an asset manager is not supported by the reality of the business and we do not see why boards would be likely to assume such a uniform view."). 
strategy? The paradigmatic universal owner is an index fund, which offers investors the opportunity to secure market returns for a low cost. But in order to keep costs low, the index fund needs to minimize overall expenditures - including investments in company-specific information and market research.228 For this reason, index funds primarily focus on governance reforms that can be implemented at scale.229 They are not well-positioned to solve problems that have generated substantial debate among informed researchers, such as how companies can minimize risks from climate change. They might not even be able to identify the worst offenders. 230

And even if index funds had sufficient knowledge to identify problematic companies and push them to sacrifice profits in order to minimize portfolio-level risk, how would they implement that strategy? Their principal tools are governance rights, and shareholder voting is a crude tool to bring about specific operational changes. In addition, universal owners have tended to follow rather than lead. For example, the largest universal owners never bring shareholder proposals themselves, and they fail to consistently vote in favor of the prosocial shareholder proposals that are brought by others.231 Perhaps behind the scenes engagement would be more effective than voting at driving firm-specific changes, but meaningful engagement is even more time consuming and expensive. 232 In addition, index fund engagement may be ineffective without a credible exit threat.233

In sum, shareholders - even the large, universal owners - are unlikely to be the solution to the problem of corporate irresponsibility via their governance rights. Yes, shareholders can push management to focus on long-term wealth creation,234 or take a risk on corporate social responsibility that is NPV uncertain, but when it comes to public interested decisions, these are unlikely to be catalyzed by shareholders alone.

228 Dorothy S. Lund, The Case Against Passive Shareholder Voting, 43 J. Corp. L. 101 (2018).

229 Id.; Marcel Kahan \& Edward Rock, Index Funds and Corporate Governance: Let Shareholders Be Shareholders (N.Y. Univ. Sch. of Law Law \& Economics Research Paper Series, Working Paper No. 18-39, 2019), https://papers.ssrn.com/sol3/papers.cfm?abstract_id=3295098.

230 ESG disclosures could help with this issue, however. See Fisch, Lipton, supra note XX.

231 Lucian Bebchuk \& Scott Hirst, Index Funds and the Future of Corporate Governance: Theory, Evidence, and Policy, 119 Colum. L. REV. (forthcoming Dec. 2019); Tim McLaughlin \& Ross Kerber, Index Funds Invest Trillions But Rarely Challenge Management, Reuters (Oct. 8, 2019), https://www.reuters.com/article/us-usa-fundsindex-specialreports/index-funds-invest-trillions-but-rarely-challenge-managementidUSKBN1WN107?feedType=RSS\&feedName=newsOne; Jeff Sommer, Want a Bigger Say on Corporate Behavior? Move Your Money, NY Times, https://www.nytimes.com/2019/12/12/business/corporate-behaviormove-your-money.html?smid=nytcore-ios-share. But see Barzuza et al, supra note 54, who describe the State Street campaign to improve board diversity. In this campaign, State Street sought to increase board diversity and supported the goal with meaningful action - votes against nominating directors at all male boards. And their activity attracted attention from others, including BlackRock and Vanguard, who also targeted the issue. But this example demonstrates the limits of universal owner activism. The universal owner benefits from economies of scale and scope: they can set market wide standards and then enforce them across their large portfolios, as they did with the board diversity campaign. See Rock and Kahan, supra note XX. But for E\&S issues that do not lend themselves to broad portfolio-level application - which is to say, most E\&S issues - universal owners will lack the necessary information and resources to engage in meaningful activism. See Barzuza et al., supra note 54 (describing the Big Three's efforts in environmental activism).

232 See Lund, supra note XX.

233 See, e.g., Marco Becht et al., Corporate Governance Through Voice and Exit (Nov. 8, 2019) (unpublished manuscript), https://papers.ssrn.com/sol3/papers.cfm?abstract_id=3456626.

234 See Hyun-Dong Kim, Do Long-Term Institutional Investors Promote Corporate Social Responsibility

Activities?, 101 Journal of Banking and Finance (2019)

https://www.sciencedirect.com/science/article/pii/S0378426618302681. 
Of course, shareholders - as well as other stakeholders - can shift the objective function of a firm by influencing the type of conduct that is profit maximizing for the company. Indeed, consumer boycotts, employee strikes, and investor divestment campaigns all attempt to alter company conduct by identifying companies with harmful business practices and affecting their bottom line. As discussed, the corporate social responsibility bond is not intended to be a substitute for these practices, but a complement. Indeed, even when these campaigns are not successful, they may narrow the distance between profit sacrificing and profit maximizing enough to allow bond donors to close the gap.

The insight that corporate stakeholders may value corporate social responsibility more highly than shareholders also reflects on other ongoing conversations within corporate and securities law. For example, Ann Lipton has emphasized the importance of corporate disclosures for the general public, and described how securities law-which mandates disclosure of information that would be material to investors - might not achieve the right amount of disclosure from a social welfare perspective. 235 Her insight supports proposals to increase stakeholder disclosure that would shine light on socially harmful corporate behavior-information that would also facilitate the operation of the corporate social responsibility bond market.236

But the fact of the matter is that advocates of social responsibility, for now, are stuck working within the system that we have - a system that puts shareholder interests first. And this leads to some perverse consequences. For example, stakeholders attempt to bring shareholder proposals that would benefit workers, the environment, and society, by couching those proposals in wealth maximization terms. 237 This is not only misleading, 238 it strains the entire system.239 Corporate voting and corporate disclosure were designed for a narrow purpose-accountability to shareholders.240 When these systems are asked to serve too many masters, we end up in the situation we have today: too many votes, and too much information, for the typical investor to focus on deeply and carefully.241 If we want companies to pay closer attention to environmental and social issues that are priorities for corporate stakeholders, and continue to be constrained to operate within the tools at hand, we need to recognize the collateral consequences that come from using a system that was intended for a different purpose.

This analysis speaks to the larger question of whether we should continue to orient our system of corporate law and governance around shareholders, given that it is not always socially optimal to do so. The answer may be no, at least, not always. There are places where giving rights to

235 Ann M. Lipton, Not Everything Is About Investors: The Case for Mandatory Stakeholder Disclosure, YALE J. ON REG. (forthcoming).

236 Id.; see also Fisch, supra note XX.

237 Id.

$238 \mathrm{Id}$.

239 See, e.g., Frank H. Easterbrook \& Daniel R. Fischel, Voting in Corporate Law, 26 J.L. \& Econ. 395 (1983) (“It is well known, however, that when voters hold dissimilar preferences it is not possible to aggregate their preferences into a consistent system of choices. If a firm makes inconsistent choices, it is likely to self destruct.").

240 Id.

241 See Strine, supra note XX ("If we want institutional investors to wisely focus their voting decisions on sustainable corporate performance, we must reduce the continual mini-referendums occurring each year and the huge number of votes shareholders must cast ...."). 
stakeholders - whether they be informational rights, or legal rights — would likely result in positive changes from a social welfare perspective. As discussed, giving corporate stakeholders voice would enable corporations to make some public interested choices. But the difficulty is designing a system that would empower outsiders without eliminating the accountability that comes from a shareholder-wealth maximization default.242 In addition, it will be challenging to reorient our system of law, markets, and culture — what Elizabeth Pollman and I have dubbed "The Corporate Governance Machine" - in a new direction.243 In the meantime, as that project forges on, this paper proposes a course of action that would allow corporate outsiders to influence corporate decisionmaking now-one decision at a time.

\section{Conclusion}

Corporations are powerful entities: they affect all of us - as consumers, investors, employees, and as citizens of a government that is increasingly subject to corporate influence.244 And yet, only shareholders are given control rights. As such, corporate stakeholders are woefully ill-positioned to affect corporate behavior, even when doing so would vastly improve public welfare. We have begun to re-consider the normative desirability of the long-accepted shareholder primacy model.245 But there is no consensus about what model should take its place. As that discussion moves forward, this Article offers a tool that could allow outsiders to alter corporate decision-making without any delay. More specifically, the corporate social responsibility bond supports a Coasian bargain between stakeholders and the company and that could therefore change the course of corporate decisionmaking when the welfare benefits are very great. Although this course of action will not solve the problem of corporate irresponsibility, it is a promising tool that could motivate corporate change in a world that remains anchored to wealth maximization.

242 See Henry HANSMANN, THE OWNership OF ENTERPRISE 44 (2000); Berle supra note 125. But see Grant Hayden \& Matthew Bodie, Arrow's Theorem and the Exclusive Shareholder Franchise, 62 Vand. L. Rev. 101 (2009). 243 See supra note XX.

244 See Citizens United; https://pdfs.semanticscholar.org/1c83/f46c4a755e8fc42af095e5e8ee49d12c7152.pdf. 245 https://papers.ssrn.com/sol3/papers.cfm?abstract_id=204528 